\title{
Drosophila Neprilysins Are Involved in Middle-Term and Long-Term Memory
}

\author{
Oriane Turrel, Aurélie Lampin-Saint-Amaux, Thomas Préat, and Valérie Goguel \\ Genes and Dynamics of Memory Systems, Brain Plasticity Unit, Centre National de la Recherche Scientifique, ESPCI-ParisTech, PSL Research University, \\ 75005 Paris, France
}

Neprilysins are type II metalloproteinases known to degrade and inactivate a number of small peptides. Neprilysins in particular are the major amyloid- $\beta$ peptide-degrading enzymes. In mouse models of Alzheimer's disease, neprilysin overexpression improves learning and memory deficits, whereas neprilysin deficiency aggravates the behavioral phenotypes. However, whether these enzymes are involved in memory in nonpathological conditions is an open question. Drosophila melanogaster is a well suited model system with which to address this issue. Several memory phases have been characterized in this organism and the neuronal circuits involved are well described. The fly genome contains five neprilysin-encoding genes, four of which are expressed in the adult. Using conditional RNA interference, we show here that all four neprilysins are involved in middle-term and long-term memory. Strikingly, all four are required in a single pair of neurons, the dorsal paired medial (DPM) neurons that broadly innervate the mushroom bodies (MBs), the center of olfactory memory. Neprilysins are also required in the MB, reflecting the functional relationship between the DPM neurons and the MB, a circuit believed to stabilize memories. Together, our data establish a role for neprilysins in two specific memory phases and further show that DPM neurons play a critical role in the proper targeting of neuropeptides involved in these processes.

Key words: dorsal paired medial neurons; Drosophila; long-term memory; mushroom bodies; neprilysin; olfactory conditioning

\section{Significance Statement}

Neprilysins are endopeptidases known to degrade a number of small peptides. Neprilysin research has essentially focused on their role in Alzheimer's disease and heart failure. Here, we use Drosophila melanogaster to study whether neprilysins are involved in memory. Drosophila can form several types of olfactory memory and the neuronal structures involved are well described. Four neprilysin genes are expressed in adult Drosophila. Using conditional RNA interference, we show that all four are specifically involved in middle-term memory (MTM) and long-term memory (LTM) and that their expression is required in the mushroom bodies and also in a single pair of closely connected neurons. The data show that these two neurons play a critical role in targeting neuropeptides essential for MTM and LTM.

\section{Introduction}

Neprilysin proteins are zinc-dependent endopeptidases that inactivate small peptides. They are mainly type II integral membrane proteins, although in rare cases they can be cleaved or

Received 0ct. 12, 2015; revised July 4, 2016; accepted July 25, 2016.

Author contributions: T.P. and V.G. designed research; 0.T., A.L.-S.-A., and V.G. performed research; 0.T., T.P., and V.G. analyzed data; 0.T. and V.G. wrote the paper.

T.P. received grant support from the French Agence Nationale de la Recherche (11BSV40071) and the Fondation pour la Recherche Médicale (DEQ20140329540). 0.T. received support from the Fonds de I'ESPCI-Georges Charpak. We thank Honorine Lucchi for technical help and all of the members of our laboratory for valuable discussions and for critically reading this manuscript.

The authors declare no competing financial interests.

Correspondence should be addressed to Valérie Goguel, Genes and Dynamics of Memory Systems, Brain Plasticity Unit, CNRS, ESPCI-ParisTech, PSL Research University, 10 rue Vauquelin, 75005 Paris, France. E-mail: valerie.goguel@espci.fr.

DOI:10.1523/JNEUROSCI.3730-15.2016

Copyright (C) 2016 the authors $\quad 0270-6474 / 16 / 369535-12 \$ 15.00 / 0$ secreted. Their active site faces the extracellular space and they can be present at presynaptic sites (Fukami et al., 2002; Iwata et al., 2004). Neprilysins play a key role in brain function by terminating neuropeptide signaling at the cell surface (Turner, 2003) and have been identified in various tissues in various organisms, indicating evolutionarily conserved functions. They are involved in many neuronal processes from axonal regeneration and synaptic plasticity to neuroinflammation and, at the behavioral level, have been implicated in motor function, anxiety, circadian rhythms, and sleep (Nalivaeva et al., 2012a).

Neprilysins are also the major amyloid- $\beta$ (A $\beta)$ peptidedegrading enzymes (Nalivaeva et al., 2012a; Marr and Hafez, 2014) and, as such, are thought to be key to Alzheimer's disease (AD), in which the first symptom is a loss of memory. AD brains show decreased levels of neprilysin expression and activity (Yasojima et al., 2001; Caccamo et al., 2005; Wang et al., 2010; Zhou et al., 2013). In murine models of AD, neprilysin overexpression 

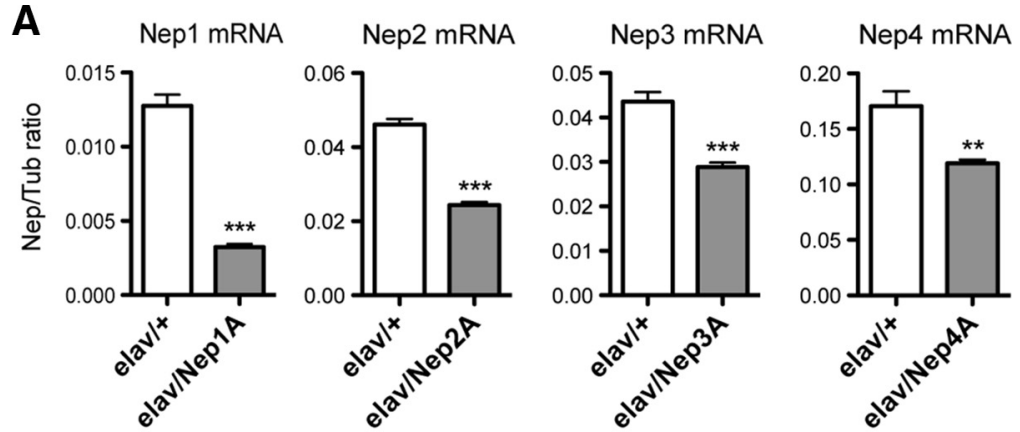

B Nep1

1-cycle (2 h)

$\alpha / \beta$ (induced)
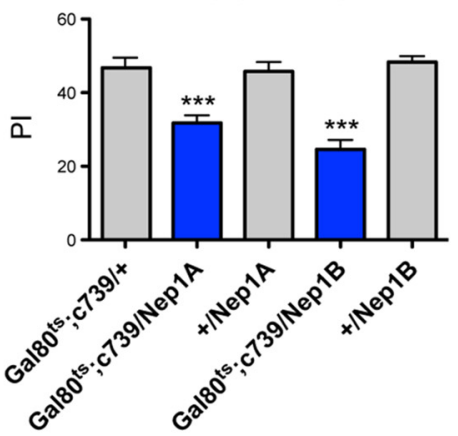

D

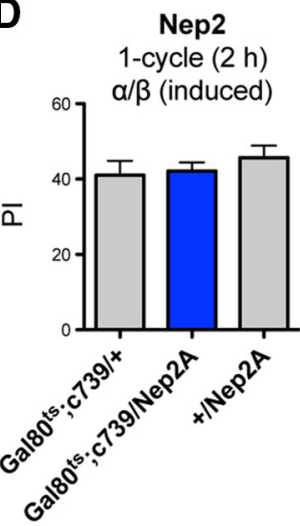

E

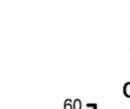

\section{Nep3}

1-cycle $(2 \mathrm{~h})$ $\alpha / \beta$ (induced)

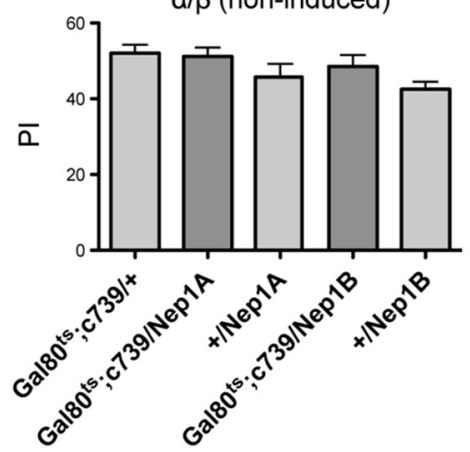

$\bar{\alpha}$

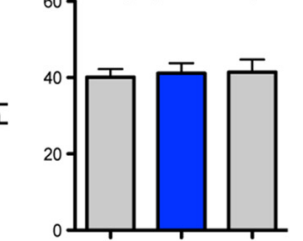

$\bar{\alpha}$
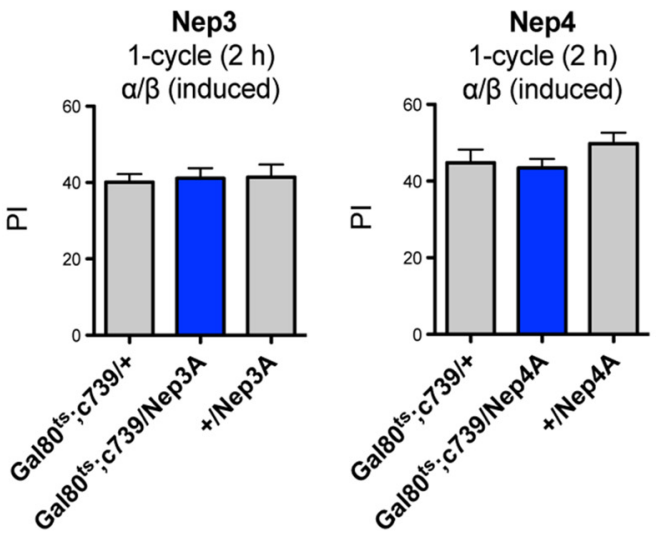

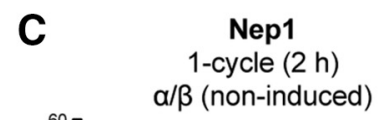

Nep2, Nep3, Nep4

1-cycle $(2 \mathrm{~h})$

$\alpha / \beta$ (induced)

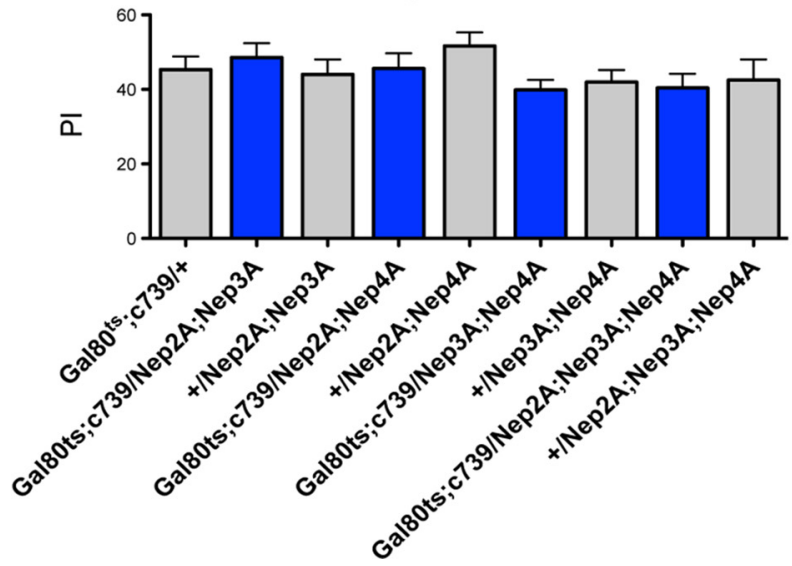

Figure 1. Nep1 inhibition in the adult $\alpha / \beta$ MB neurons induces a MTM deficit. $\boldsymbol{A}$, Neprilysin mRNA is targeted efficiently by RNAi-Nep constructs. Shown are qPCR analyses of neprilysin expression. Total RNA was extracted from elav/+ and elav/RNAi-Nep fly heads and further reverse transcribed with olig(dT) primers. Resulting cDNA was quantified using tubulin (Tub) expression as a attenuates memory deficits (Poirier et al., 2006; Spencer et al., 2008; Park et al., 2013), whereas neprilysin deficiency aggravates the behavioral phenotypes (Hüttenrauch et al., 2015). It has also been shown that neprilysin inhibition improves memory in aged mice, an effect that is not mediated through $\mathrm{A} \beta$ degradation (Walther et al., 2009). Nalivaeva et al. (2012b) showed that administration of valpoic acid, which can upregulate neprilysin expression, could restore neprilysin activity and memory deficit caused by prenatal hypoxia in adult rats, which points to a role in memory. However, whether neprilysin is involved in memory in nonpathological situations is still an open question.

To find out whether neprilysin is required for memory in physiological conditions, we used Drosophila melanogaster, a model organism that allows efficient conditional silencing in selected neuronal structures. The fly genome contains five neprilysin-encoding genes (Bland et al., 2008). Neprilysins 1-4 (Nep1-4) are expressed in all developmental stages, whereas Nep5-specific transcripts are undetectable, indicating that this gene is only marginally expressed, if at all, in Drosophila (Chintapalli et al., 2007; Meyer et al., 2011). Nep1 is the fly ortholog of human neprilysin (hNEP) (Turner et al., 2001). Catalytic activity has been demonstrated for two Drosophila neprilysins, Nep2 (Thomas et al., 2005; Bland et al., 2007) and Nep4 (Meyer et al., 2009).

$\leftarrow$

reference. Results are shown as ratios to the reference (Nep1: $t$ test, ${ }^{* * *} p<0.0001, n=4$; Nep2: $t$ test, ${ }^{* * *} p<0.0001, n=$ 6; Nep3: $t$ test, ${ }^{* * *} p=0.0008, n=4$; Nep4: $t$ test, ${ }^{* *} p=$ $0.0094, n=4)$. $B$, $C$, Nep1 expression in adult $\alpha / \beta$ MB neurons is involved in MTM. $\boldsymbol{B}$, After $3 \mathrm{~d}$ of induction, $\mathrm{Gal} 8 \mathrm{O}^{\mathrm{ts}}$; C739/Nep1A and $/$ Nep $1 B$ flies exhibit MTM deficits $\left(F_{(4,45)}=\right.$ 20.98, $p<0.0001, n \geq 8$; post hoc Newman-Keuls test, Gal80 ${ }^{\text {ts }}, \mathrm{c} 739 / \mathrm{Nep} 1 \mathrm{~A}$ vs Gal80 ${ }^{\text {ts }}, \mathrm{c7391+}{ }^{* * *} p<0.001$, Gal80 ${ }^{\text {ts }} ;$ C739/Nep1A vs $+/$ Nep $1 A *^{* * *} p<0.001$, Gal80 ${ }^{\text {ts }}$;

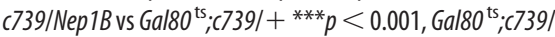
Nep1B vs $+/$ Nep $\left.1 B^{* * *} p<0.001\right)$. C, In the absence of Gal4 induction, Gal80 ${ }^{\text {ts }} ; 7739 /$ Nep $1 A$ and $/$ Nep $1 B$ flies exhibit similar MTM scores to their respective genetic controls $\left(F_{(4,64)}=\right.$ 2.039, $p=0.1003, n \geq 11)$. D, $\boldsymbol{E}$, Nep2, Nep3, and Nep4 silencing in adult $\alpha / \beta \mathrm{MB}$ neurons does not alter MTM. $\boldsymbol{D}$, Single Nep knock-down MTM analyses with the $\mathrm{Gal} 8 \mathrm{O}^{\text {ts }}$; 7339 driver. RNAi-expressing flies show similar MTM scores to the genetic controls (Nep2A: $F_{(2,26)}=0.5832, p=0.5658, n=9$; Nep3A: $F_{(2,26)}=0.06404, p=0.9381, n=9$; Nep4A: $\left.F_{(2,25)}=1.233, p=0.3100, n \geq 8\right)$. $E$, Analyses of double and triple Nep knock-down with the Gal80 ${ }^{\text {ts }}$; 739 driver. RNAiexpressing flies show similar MTM scores to their genetic controls $\left(F_{(6,106)}=1.250, p=0.2874, n \geq 10\right)$. Error bars indicate mean \pm SEM. PI, Performance index. 
The fly brain, despite its relative simplicity, is highly structured and can drive sophisticated behaviors. It is extensively used as a model to study memory. The molecular mechanisms underlying memory are conserved from flies to mammals and the neuronal structures involved are well described (Heisenberg, 2003). In particular, the mushroom bodies (MBs) are known as the central integrative brain structure for olfactory memory (de Belle and Heisenberg, 1994; Gerber et al., 2004; Krashes et al., 2007). The MB is a bilateral structure composed of 4000 intrinsic neurons called Kenyon cells that are classed into three different subtypes with axons that form two vertical $\left(\alpha\right.$ and $\left.\alpha^{\prime}\right)$ and three medial $\left(\beta, \beta^{\prime}\right.$ and $\left.\gamma\right)$ lobes (Crittenden et al., 1998).

Here, we address the role of Nep1-4 in memory using conditional RNA interference (RNAi) in healthy young flies. We show that each neprilysin expressed in the adult fly is specifically involved in the formation of middle-term memory (MTM) and long-term memory (LTM). Interestingly, we found that the expression of each neprilysin is required in the $\mathrm{MB}$ and also in a single pair of large neurons, the dorsal paired medial (DPM) neurons (Waddell et al., 2000). DPM neurons are known to innervate all of the $\mathrm{MB}$ lobes broadly and mediate the consolidation of memories (Keene et al., 2004). Our data thus show that DPM neurons play a key role in the degradation of neuropeptides, a critical process for sustaining MTM and LTM.

\section{Materials and Methods}

Drosophila stocks. Drosophila wild-type strain Canton Special (CS) and mutant flies were raised on standard medium at $18^{\circ} \mathrm{C}$ in $60 \%$ humidity in a $12 \mathrm{~h} \mathrm{light/dark} \mathrm{cycle.} \mathrm{All} \mathrm{strains} \mathrm{used} \mathrm{for} \mathrm{memory} \mathrm{experiments} \mathrm{were}$ outcrossed to the CS background. RNAi-Nep lines were obtained from the Vienna Drosophila Resource Center (Austria) for RNAi-Nep1 (Nep1A: 27537, Nep1B: 108860), RNAi-Nep2 (Nep2A: 23172, Nep2B: 102584), RNAi-Nep3 (Nep3B: 37804) and RNAi-Nep4 (Nep4A: 16669, Nep4B: 100189) and from the National Institute of Genetics (Japan) for RNAi-Nep3 (Nep3A: 9565-R1). The UAS-Dicer2 line (24650) was obtained from the Bloomington Drosophila Stock Center (Indiana University, National Institutes of Health P40OD018537). Gal4 drivers were used to achieve RNAi expression. The elav-Gal4 driver was used for pan-neuronal expression, tubulin-Gal80 ${ }^{\text {ts }} ; 238 Y\left(\right.$ Gal80 $\left.^{\text {ts }} ; 238 Y\right)$ for conditional expression in the MB, tubulin-Gal80 $0^{\mathrm{ts}} ; \mathrm{c739}\left(\mathrm{Gal}_{80}{ }^{\mathrm{ts}} ; \mathrm{c739}\right)$ for conditional expression in $\alpha / \beta$ neurons, MB247-Gal80;c316 (MB-Gal80; c316) and VT64246 (Vienna Drosophila Resource Center, Austria) for constitutive expression in DPM neurons, and tubulin-Gal80 ${ }^{\text {ts }} ;$ VT64246 $\left(\right.$ Gal80 $^{\text {ts }}$;VT64246) for conditional expression in DPM neurons. To induce RNAi expression specifically in adults, the TARGET system was used as described by McGuire et al. (2003): flies were kept at $30^{\circ} \mathrm{C}$ for $3 \mathrm{~d}$ before conditioning, and also until memory test for anesthesia-resistant memory (ARM) and LTM analyses.

Behavioral experiments. Flies were trained with classical olfactory aversive conditioning protocols as described by Pascual and Préat (2001). Training and testing were performed at $25^{\circ} \mathrm{C}$ in $80 \%$ humidity. Conditioning was performed on samples of 25-35 flies 3-4 d old with 3-octanol ( $~ 95 \%$ purity; Sigma-Aldrich) and 4-methylcyclohexanol (99\% purity; Sigma-Aldrich) at $0.360 \mathrm{~mm}$ and $0.325 \mathrm{~mm}$, respectively. Odors were diluted in paraffin oil (VWR International). Memory tests were performed with a T-maze apparatus (Tully and Quinn, 1985). Flies were given $1 \mathrm{~min}$ to choose between 2 arms, each delivering a distinct odor. An index was calculated as the difference between the numbers of flies in each arm divided by the sum of flies in both arms. The average of two reciprocal experiments gave a performance index. For odor avoidance tests after electric shock and response to electric shock, flies were treated as described by Pascual and Préat (2001). To analyze consolidated memory, before five-spaced conditioning, groups of 40 flies were placed for $17 \mathrm{~h}$ at $30^{\circ} \mathrm{C}$ in feeding tubes (Falcon 2017) containing Whatman filter paper strip $(1.0 \times 2.5 \mathrm{~cm})$ soaked with a total $125 \mu \mathrm{l}$ of sucrose solution (5\%, Sigma-Aldrich) with or without cycloheximide (CXM, $35 \mathrm{~mm}$;
Table 1. Shock reactivity and olfactory acuity of flies expressing RNAi-Nep1A or RNAi-Nep1B in adult $\boldsymbol{\alpha} / \boldsymbol{\beta}$ neurons

\begin{tabular}{|c|c|c|c|}
\hline \multirow[b]{2}{*}{ Genotype } & \multirow[b]{2}{*}{ Shock reactivity } & \multicolumn{2}{|l|}{ Olfactory acuity } \\
\hline & & Octanol & Methylcyclohexanol \\
\hline Gal80's $;(7399 /+$ & $74.88 \pm 3.953$ & $55.44 \pm 4.193$ & $46.06 \pm 3.738$ \\
\hline Gal80 $;$,c739/Nep1A & $77.38 \pm 4.637$ & $59.00 \pm 5.568$ & $42.50 \pm 4.826$ \\
\hline$+/$ Nep1A & $79.88 \pm 4.286$ & $51.00 \pm 6.614$ & $46.38 \pm 4.728$ \\
\hline Gal80 $0^{\text {ts. }} ; 7399 /$ Nep1B & $79.75 \pm 6.135$ & $54.00 \pm 6.094$ & $45.25 \pm 3.867$ \\
\hline$+/$ Nep1B & $73.38 \pm 5.161$ & $59.25 \pm 6.619$ & $52.00 \pm 4.342$ \\
\hline
\end{tabular}

Data are shown as means \pm SEM. After $3 \mathrm{~d}$ of induction, neither shock reactivity $\left(F_{(4,47)}=0.3371, p=0.8515\right.$, $n \geq 8)$ nor olfactory acuity for octanol $\left(F_{(4,47)}=0.3231, p=0.8610, n \geq 8\right)$ and methylcyclohexanol $\left(F_{(4,47)}=\right.$ $0.5304, p=0.7140, n \geq 8$ ) is impaired in flies expressing RNAi-Nep1A or Nep1B under the control of the Gal80 ${ }^{t s}$; c739 driver.

Sigma-Aldrich). Flies were transferred to standard food vials $30 \mathrm{~min}$ before training. After training, flies were kept in standard food vials at $30^{\circ} \mathrm{C}$ for $24 \mathrm{~h}$ until memory tests were performed.

Quantitative PCR analyses. Flies were raised at $25^{\circ} \mathrm{C}$ before total RNA extraction from 50 female heads using the RNeasy Plant Mini Kit (Qiagen). Samples were reverse-transcribed with oligo(dT)20 primers using the SuperScript III First-Strand kit (Life Technologies) according to the manufacturer's instructions. Level of the target cDNA was compared against level of $\alpha$-Tub84B (Tub, CG1913) cDNA, which was used as a reference. Amplification was performed using a LightCycler 480 (Roche) and the SYBR Green I Master mix (Roche). Reactions were performed in triplicate. The specificity and size of amplification products were assessed by melting curve analyses and agarose gel electrophoresis, respectively. Expression relative to reference is expressed as a ratio $\left(2^{-\Delta C p}\right.$, where $C p$ is the crossing point).

Statistical analyses. Memory scores are displayed as mean \pm SEM. Quantitative mRNA measurements were analyzed from $2^{-\Delta \mathrm{Cp}}$ using Student's $t$ tests, with significance threshold set at $p \leq 0.05$. For behavioral experiments, scores resulting from all genotypes were analyzed using one-way ANOVA followed, if significant at $p \leq 0.05$, by NewmanKeuls multiple-comparisons tests. The overall ANOVA $p$-value is given in the legends, along with the value of the corresponding Fisher distribution $F_{(x, y)}$, where $x$ is number of degrees of freedom for groups and $y$ is total number of degrees of freedom for the distribution. Asterisks on the figure denote the least significant of the pairwise post hoc comparisons between the genotype of interest and its controls following the usual nomenclature.

\section{Results}

\section{Nep1 expression is required in the adult MB for MTM}

The fly expresses four neprilysins, Nep1-4 (Meyer et al., 2011), one of which, Nep1, was shown to be expressed in the MB (Sitnik et al., 2014). To analyze the potential involvement of fly neprilysins in memory, we used the classical conditioning of an odor-avoidance response. In this paradigm, groups of flies are successively exposed to two distinct odors, only one of which is associated with electric pulses. Distinct phases of associative aversive memory can then be differentiated (Isabel and Préat, 2008; Bouzaiane et al., 2015). Learning is assessed immediately after a single conditioning, whereas MTM is assessed $2 \mathrm{~h}$ later. The fly can also produce two antagonistic forms of consolidated memory: ARM is formed after five massed cycles of conditioning, whereas the robust LTM is only formed after five cycles spaced at 15 min rest intervals. Crucially, LTM is the only memory phase dependent on de novo protein synthesis (Tully et al., 1994).

To assess the involvement of neprilysins in memory, neprilysin expression was knocked down using RNAi-mediated silencing. The efficiency of four RNAi constructs targeting Nep1, Nep2, Nep3, and Nep4, respectively, was assessed using the panneuronal elav-Gal4 driver (elav) (Brand and Perrimon, 1993). Neprilysin expression in fly heads was quantified by real-time PCR. The expression of each specific RNAi construct (elav/Nep) 

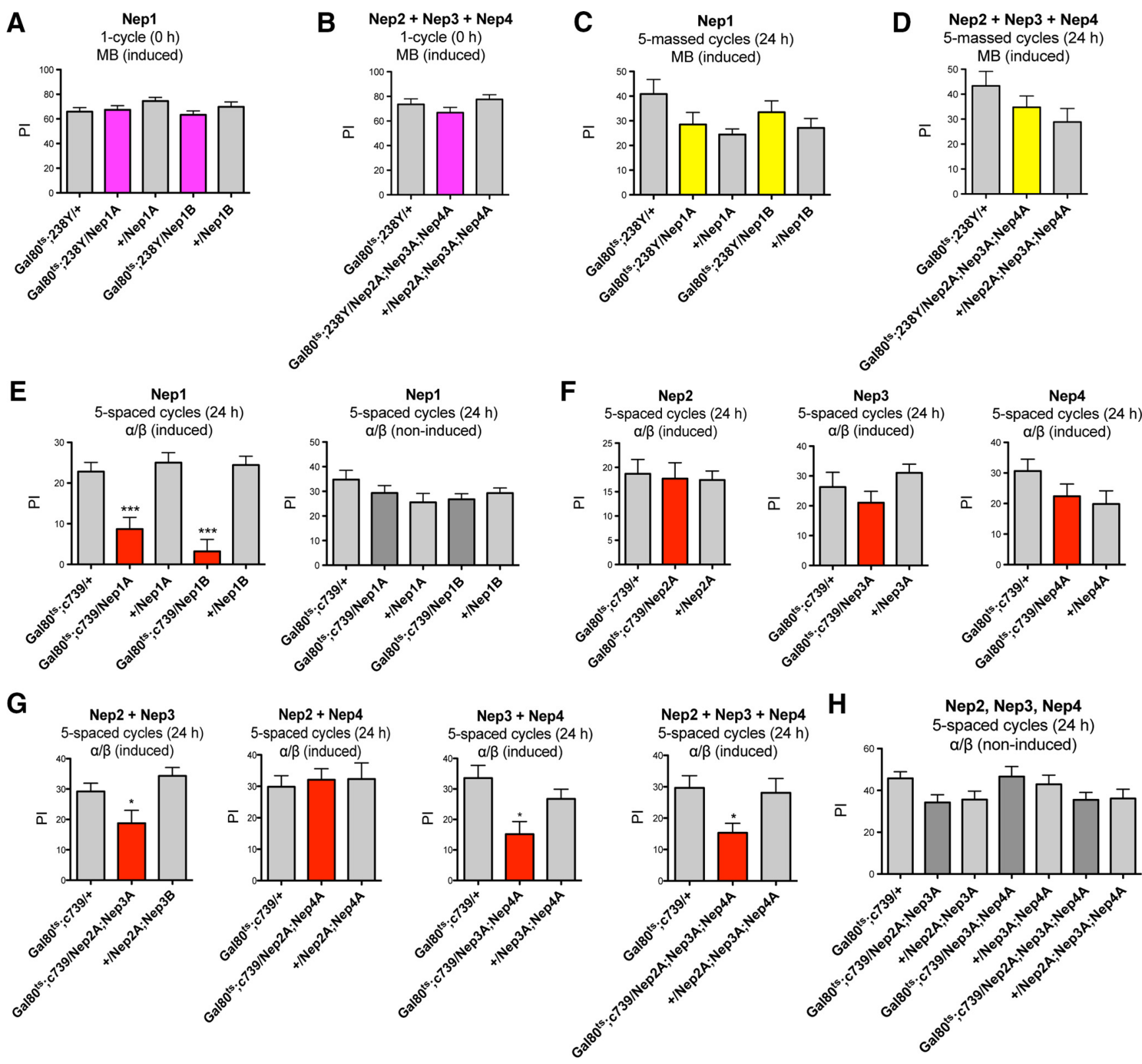

$\mathbf{H}$

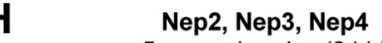

5 -spaced cycles $(24 \mathrm{~h})$ $\alpha / \beta$ (non-induced)

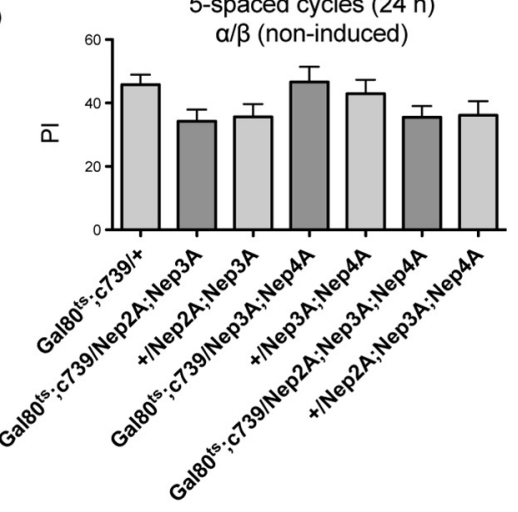

Figure 2. Neprilysin inhibition in the adult MB induces LTM deficits. $\boldsymbol{A}, \boldsymbol{B}$, Neprilysin silencing in the adult MB does not affect learning. $\boldsymbol{A}, \mathrm{Gal} 80^{\text {ts }} ; 238 Y /$ Nep $1 A$ and $/$ Nep $1 B$ flies exhibit similar learning scores to the genetic controls $\left(F_{(4,49)}=1.591, p=0.1932, n=10\right)$. B, Concomitant silencing of Nep2, Nep3, and Nep4 does not affect learning. Gal80 ${ }^{\text {ts }} ; 238 Y /$ Nep2A;Nep3A;Nep4A flies exhibit similar learning scores to the genetic controls $\left(F_{(2,27)}=1.681, p=0.2066, n \geq 9\right)$., $\boldsymbol{D}$, Neprilysin silencing in the adult MB does not impact ARM. $\boldsymbol{C}$, Gal80 ${ }^{\text {ts }} ; 238 Y /$ Nep $1 A$ and $/$ Nep $1 B$ flies exhibit similar memory scores to the genetic controls $\left(F_{(4,73)}=2.075, p=0.0934, n \geq 14\right)$. D. Concomitant silencing of Nep2, Nep3, and Nep4 does not affect ARM. Gal80 ${ }^{\text {ts }} ; 238 Y /$ Nep2A;Nep3A; Nep4A flies exhibit similar ARM scores to the genetic controls $\left(F_{(2,41)}=1.929, p=0.1589, n=14\right)$. $\boldsymbol{E}-\boldsymbol{H}$, LTM analyses. $\boldsymbol{E}$, Nep1 expression is required in adult $\alpha / \beta$ neurons for LTM formation. After

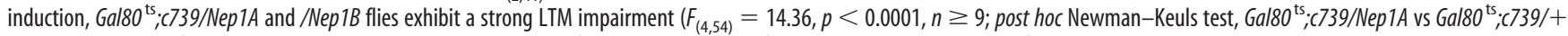

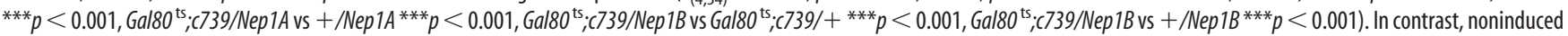
flies show similar LTM scores to the genetic controls $\left(F_{(4,40)}=1.399, p=0.2539, n \geq 8\right) . F$, Nep2, Nep3, and Nep4 inhibition in adult $\alpha / \beta$ neurons does not alter LTM (Nep2A: $F_{(2,29)}=0.06101$, $p=0.9409, n=10 ; \operatorname{Nep3A}: F_{(2,50)}=2.183, p=0.1237, n \geq 10 ;$ Nep4A: $\left.F_{(2,50)}=1.380, p=0.2615, n \geq 11\right)$. G, LTM analyses of double and triple Nep knock-down in adult $\alpha / \beta$ neurons. Nep2 + Nep3, Nep3 + Nep4, and Nep2 + Nep3 + Nep4 knock-down alter LTM (Nep2A;Nep3A: $F_{(2,43)}=5.785, p=0.0061, n \geq 14 ;$ post hoc Newman-Keuls test, Gal80 ts. ${ }^{\text {c } 739 / N e p 2 A ; N e p 3 A}$

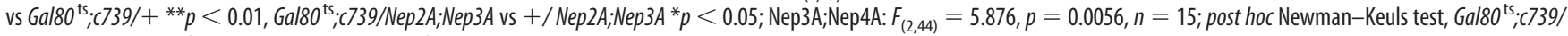

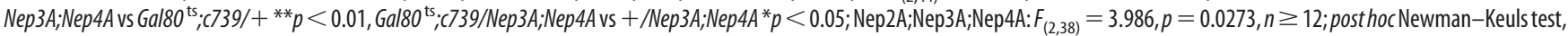

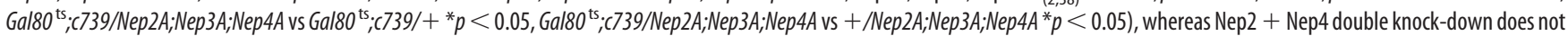
$\left(F_{(2,38)}=0.1079, p=0.8980, n=13\right) . \boldsymbol{H}$, In the absence of induction, all genotypes exhibit normal LTM scores $\left(F_{(2,42)}=0.2195, p=0.8039, n \geq 14\right)$.

led to a reduced expression of its targeted gene by $75 \%$ (Nep1), $50 \%$ (Nep2), 30\% (Nep3), and 25\% (Nep4) compared with the elav/+ control (Fig. 1A). These data thus establish that the distinct RNAi constructs efficiently target each distinct neprilysin mRNA.

Preliminary experiments using the ubiquitous daughterlessGal4 driver suggested that the expression of each of the four neprilysins is required for MTM (data not shown). Because MTM has been shown to involve the $\alpha / \beta \mathrm{MB}$ neurons (Bouzaiane et al., 2015), we further analyzed memory using the $c 739$ driver known to label $\alpha / \beta$ neurons specifically (Yang et al., 1995). To restrict RNAi-Nep expression to adulthood, we took advantage of the TARGET system (McGuire et al., 2003), which relies on a con- 
ventional GAL4 activation system and a temperature-sensitive Gal80 inhibitor $\left(\mathrm{Gal} 80^{\text {ts }}\right)$. Gal80 ${ }^{\text {ts }}$ represses Gal4 transcriptional activity at low temperature $\left(18^{\circ} \mathrm{C}\right)$, but this inhibition is lifted at high temperature $\left(30^{\circ} \mathrm{C}\right)$. Experiments were performed with a tub-Gal80 ${ }^{\text {ts }} ; c 739$ line $\left(\right.$ Gal80 $\left.^{\text {ts }} ; c 739\right)$. Flies expressing RNAiNep1A (VDRC 27537) $\left(\right.$ Gal80 $\left.^{\text {ts }} ; c 739 / N e p 1 A\right)$ showed an MTM deficit (Fig. 1B). To further establish the role of Nep1 in MTM formation, we needed to use a second nonoverlapping RNAi construct: RNAi-Nep1B (VDRC 108860). Because the RNAi-Nep1B line was not able to reduce Nep1 expression as efficiently as RNAi-Nep1A, we took advantage of the UAS-Dicer2 tool. Dicer is an RNase enzyme that facilitates the activation of the RNAinduced silencing complex essential for RNAi and Dicer2 overexpression in the fly has been shown to increase RNAi efficacy (Pham et al., 2004). We thus generated a line coexpressing RNAiNep1B and Dicer2 (Nep1B). Gal80 ${ }^{\text {ts }} ;$ c739/Nep1B induced flies showed a strong MTM impairment (Fig. $1 B$ ), similar to that of Gal80 ${ }^{\text {ts }}$; $739 /$ Nep1A flies. In the absence of Gal4 induction, both Gal80 $^{\text {ts }} ; c 739 / N e p 1 A$ and Gal80;c739/Nep1B flies showed normal MTM scores (Fig. $1 C$ ), indicating that the deficit observed previously was specifically caused by Nep1 inhibition in the adult $\alpha / \beta$ neurons. We verified that the ability of induced Gal80 ${ }^{\text {ts }} ; \mathrm{c739} /$ Nep1A and Gal80;c739/Nep1B flies to avoid electric shocks and their olfactory acuity to each odor after electric shock exposure were unaffected (Table 1), thus showing that they displayed normal perception of the conditioning stimuli.

In contrast, reducing Nep2, Nep3, or Nep4 expression in adult $\alpha / \beta$ neurons did not affect MTM (Fig. $1 D$ ), suggesting that Nep2,
Table 2 . Shock reactivity and olfactory acuity of flies expressing several RNAi-Nep in adult $\alpha / \beta$ neurons

\begin{tabular}{llll}
\hline & & \multicolumn{2}{l}{ Olfactory acuity } \\
\cline { 3 - 4 } Genotype & Shock reactivity & Octanol & Methylcyclohexanol \\
\hline Gal80t5; $; 739 /+$ & $74.83 \pm 4.529$ & $57.72 \pm 3.573$ & $60.00 \pm 3.085$ \\
Gal80; $; 739 /$ Nep2A;Nep3A & $67.25 \pm 5.104$ & $51.75 \pm 8.370$ & $56.88 \pm 4.206$ \\
+/Nep2A;Nep3A & $68.67 \pm 3.046$ & $61.80 \pm 5.144$ & $53.38 \pm 2.679$ \\
Gal80; $; 739 /$ Nep3A;Nep4A & $62.58 \pm 6.239$ & $51.56 \pm 4.916$ & $49.88 \pm 5.920$ \\
+/Nep3A;Nep4A & $72.67 \pm 4.926$ & $56.36 \pm 3.977$ & $49.88 \pm 3.193$ \\
Gal80; $; 739 /$ Nep2A;Nep3A;Nep4A & $65.75 \pm 6.763$ & $56.30 \pm 6.013$ & $51.75 \pm 2.218$ \\
+/Nep2A;Nep3A;Nep4A & $73.00 \pm 3.400$ & $40.86 \pm 6.636$ & $53.25 \pm 3.863$ \\
\hline
\end{tabular}

Data are shown as means \pm SEM. After $3 \mathrm{~d}$ of induction, neither shock reactivity $\left(F_{(6,83)}=0.7803, p=0.5879\right.$, $n=12)$ nor olfactory acuity for octanol $\left(F_{(6,93)}=1.445, p=0.2067, n \geq 10\right)$ and methylcyclohexanol $\left(F_{(6,59)}=\right.$ $1.149, p=0.3476, n \geq 8$ ) is impaired in flies expressing RNAi Nep2A + Nep3A, Nep3A + Nep4A or Nep2A + $\mathrm{Nep} 3 \mathrm{~A}+\mathrm{Nep} 4 \mathrm{~A}$ under the control of the Gal80 ${ }^{t 5} ; \mathrm{c} 739$ driver.

Nep3, and Nep4 expression in these neurons is not required for MTM. We next analyzed whether the lack of a MTM phenotype could be due to functional redundancy between these three neprilysins. For this purpose, we constructed flies carrying each possible double RNAi combination and the triple one. No combination of RNAi expression in the $\alpha / \beta$ neurons affected MTM (Fig. 1E). These data suggest that only Nep1 expression in the MB is required for MTM formation.

We then studied the other memory phases described in the fly. To assess learning, flies were tested immediately after a single cycle of training. Because it was shown that learning relies on $\alpha / \beta$ and also $\gamma$ neurons (Bouzaiane et al., 2015), we used a $t u b$ -
A

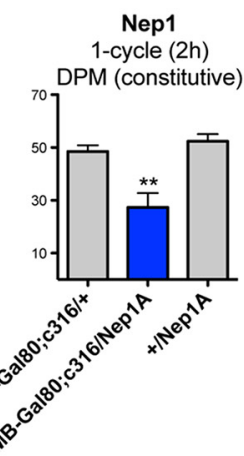

B

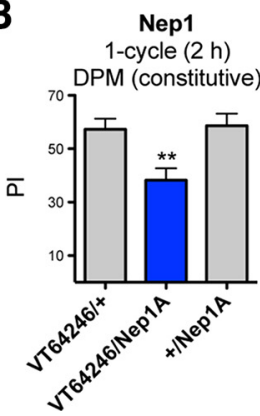

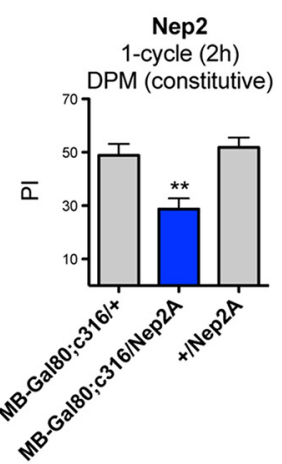

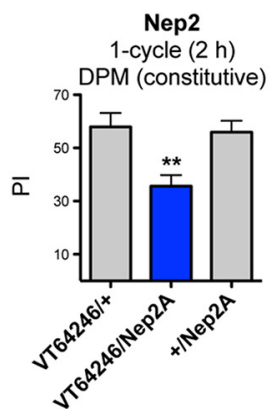

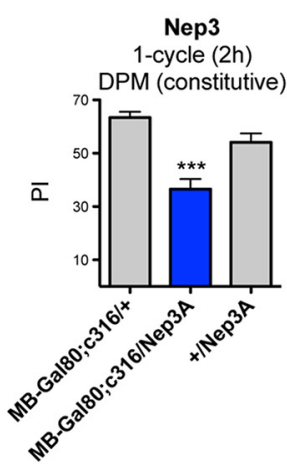
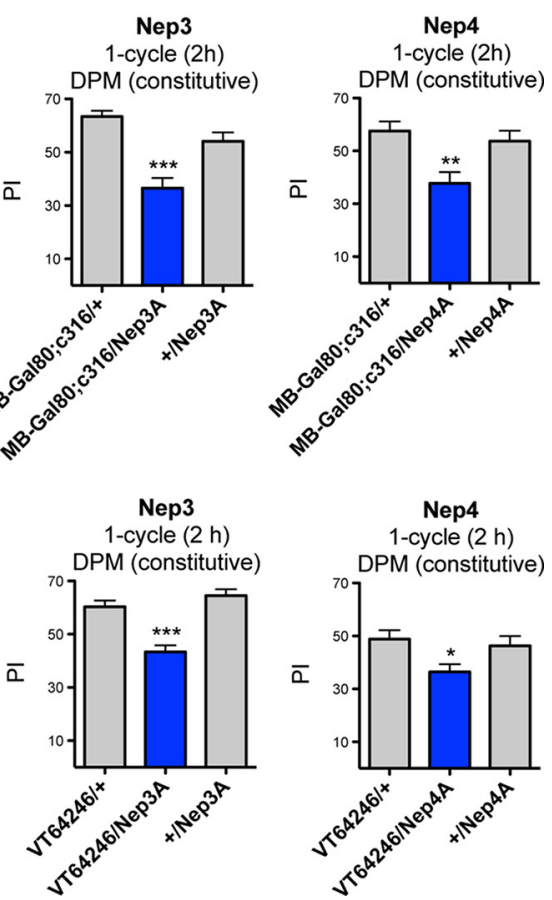

Figure 3. Constitutive inhibition of neprilysin expression in DPM neurons induces MTM deficits. A, Flies expressing RNAi-Nep under the control of the constitutive $M B$-Ga/80; 316 driver exhibit significantly lower MTM scores than the genetic controls (Nep1A: $F_{(2,31)}=11.73, p=0.0002, n \geq 8$, post hoc Newman-Keuls test, MB-Gal80; $; 316 /$ Nep $1 A$ vs MB-Gal80;c316/+ ${ }^{* *} p<0.01$, MB-Gal80;c316/Nep1A vs $+/$ Nep1A ${ }^{* * *} p<0.001 ;$ Nep2A: $F_{(2,31)}=10.72, p=0.0003, n \geq 8$, post hoc Newman-Keuls test, MB-Gal80;c316/Nep2A vs MB-Gal80;c316/+ ${ }^{* *} p<0.01$, MB-Gal80;c316/Nep2A vs +/Nep2A ${ }^{* * *} p<0.001 ;$ Nep3A: $F_{(2,47)}=18.58, p<0.0001, n=16$, post hoc Newman-Keuls test, MB-Gal80;c316/Nep3A vs MB-Gal80;c316/+ ${ }^{* * *} p<0.001, M B-G a l 80 ; c 316 / N e p 3 A$ vs $+/$ Nep3A ${ }^{* * *} p<0.001 ;$ Nep4A: $F_{(2,46)}=6.939, p=0.0024, n \geq 15$, post hoc Newman-Keuls test, MB-Gal80;c316/Nep4A vs MB-Gal80;c316/+ ${ }^{* *} p<$ 0.01 , MB-Gal80;C316/Nep4A vs + /Nep4A** $<0.01)$. B , Neprilysin inhibition in DPM neurons impairs MTM. VT64246/Nep 1A,/Nep2A,/Nep3A, and/Nep4A flies exhibit MTM deficits compared with the genetic controls (Nep1A: $F_{(2,30)}=7.403, p=0.0026, n \geq 9$, post hoc Newman-Keuls test, VT64246/Nep1A vs VT64246/+ ** $p<0.01$, VT64246/Nep1A vs $+/$ Nep1A ${ }^{* *} p<0.01$; Nep2A: $F_{(2,29)}=7.942, p=0.0019, n \geq 8$, post hoc Newman-Keuls test, VT64246/Nep2A vs VT64246/ $+{ }^{* *} p<0.01$, VT64246/Nep2A vs $+/$ Nep2A ${ }^{* *} p<0.01 ;$ Nep3A: $F_{(2,41)}=21.33, p<0.0001, n=$ 14 , posthoc Newman-Keuls test, VT64246/Nep3A vs VT64246/+ ***p $<0.001$, VT64246/Nep3A vs $+/$ Nep3A ${ }^{* * *} p<0.001 ;$ Nep4A: $F_{(2,49)}=3.872, p=0.0278, n \geq 16$, posthoc Newman-Keuls test, VT64246/Nep4A vs VT64246/+ ${ }^{*} p<0.05$, VT64246/Nep4A vs $+/$ Nep4A $\left.{ }^{*} p<0.05\right)$. 
Gal80 $^{\text {ts }} ; 238 Y$ driver to achieve inhibition in all $\mathrm{MB}$ neuronal types (Aso et al., 2009). Induced $\mathrm{Gal}^{\mathrm{ts}} ; 238 \mathrm{Y} / \mathrm{Nep} 1 \mathrm{~A}$ and Gal80 $^{\text {ts }} ; 238 Y / N e p 1 B$ flies displayed normal learning (Fig. 2A). We next assessed the effect of Nep2, Nep3, and Nep4 silencing on learning. The data show that the triple silencing did not affect learning (Fig. 2B). Together, the data suggest that no neprilysin is required in the $\mathrm{MB}$ for learning.

To analyze ARM formation, memory was tested $24 \mathrm{~h}$ after a massed conditioning. Induced Gal80 ${ }^{\text {ts }} ; 238 Y / N e p 1 A$ and $G a l 80^{\text {ts }}$; $238 Y / N e p 1 B$ flies displayed normal ARM (Fig. 2C). Gal80 ${ }^{\text {ts }} ; 238 Y /$ Nep2A;Nep3A,Nep4A induced flies also showed normal ARM scores (Fig. 2D). The data suggest that the neprilysins' expression in the $\mathrm{MB}$ is not involved in ARM formation.

To study the potential involvement of neprilysins in LTM, memory tests were performed $24 \mathrm{~h}$ after a spaced conditioning. We analyzed LTM of flies expressing RNAi-Nep 1 in $\alpha / \beta$ neurons, the $\mathrm{MB}$ neurons required for this process (Bouzaiane et al., 2015). After induction, Gal80 ${ }^{\text {ts }} ;$ c739/Nep1A and Gal80 ${ }^{\text {ts }} ; c 739 / N e p 1 B$ flies displayed LTM scores significantly lower than their genetic controls (Fig. 2E). In the absence of Gal4 induction, flies performed normally (Fig. 2E), showing that Nep1 expression in $\alpha / \beta$ neurons is involved in LTM.

Even though Nep2, Nep3, and Nep4 expression did not seem to be required in the MB for MTM, we assessed whether they were required in the $\mathrm{MB}$ for LTM. Gal80 ${ }^{\text {ts }} ; \mathrm{c739} / \mathrm{Nep} 2 \mathrm{~A}$, /Nep3A and $/$ Nep $4 A$ induced flies displayed similar LTM scores to the genetic controls (Fig. $2 F$ ). To further address the potential role of these neprilysins in the MB for LTM formation, we analyzed double and triple combination of Nep inhibition. Whereas Nep2 + Nep4 inhibition did not affect LTM, combined inhibition of Nep2 + Nep3 and Nep3 + Nep4 led to altered LTM (Fig. 2G). As expected, the triple Nep2 + Nep3 + Nep4 silencing also led to LTM impairment (Fig. 2G). In the absence of induction, all genotypes displayed normal LTM scores (Fig. $2 H$ ). Finally, we verified that these flies perceived normally the stimuli used for conditioning (Table 2). In conclusion, the expression of all four neprilysins is required in the adult MB for LTM processes.

\section{All four neprilysins are required in DPM neurons for MTM}

To further study in which brain structure Nep2, Nep3, and Nep4 are involved in MTM, we next used the MB247-Gal80;c316 driver (MB-Gal80;c316). c316 is known to label intensively the DPM neurons, a pair of neurons required for aversive MTM (Waddell et al., 2000). The MB-Gal80;c316 driver allows expression in all neurons expressing the $c 316$ Gal4 (Haynes et al., 2015) except in the $\mathrm{MB}$ neurons that express the Gal80 repressor specifically. Interestingly, the expression of any RNAi-Nep under the control of this driver ( $M B-$ Gal80;c316/Nep) led to significantly impaired MTM compared with the genetic controls (Fig. $3 A$ ). We next tested the sensory-motor capacities of the MB-Gal80;c316/Nep flies and found that they displayed wild-type shock reactivity and olfactory acuity (Table 3).

To verify that neprilysin expression is required in the DPM neurons for MTM, we used the VT64246 Gal4 driver that labels DPM neurons specifically (Lee et al., 2011). The silencing of each neprilysin achieved with the VT64246 driver led to significant MTM deficits (Fig. 3B). We conclude that the expression of all four neprilysins in DPM neurons is required for MTM formation.

We then sought to determine whether the MTM deficits shown by VT64246/Nep flies were due to developmental or acute effects. To achieve transient expression of Nep-RNAi, we generated an inducible tub-Gal80 ${ }^{\text {ts }}$;VT64246 Gal4-line $\left(\right.$ Gal $0^{\text {ts }}$;
Table 3. Shock reactivity and olfactory acuity of flies expressing RNAi-Nep(A) under the control of the MB-Gal80;c316 driver

\begin{tabular}{llll}
\hline & & \multicolumn{2}{l}{ Olfactory acuity } \\
\cline { 3 - 4 } Genotype & Shock reactivity & Octanol & Methylcyclohexanol \\
\hline MB-Gal80;c316/+ & $60.80 \pm 3.405$ & $60.63 \pm 6.219$ & $60.90 \pm 6.667$ \\
MB-Gal80;3316/Nep1A & $58.30 \pm 1.808$ & $67.10 \pm 7.114$ & $58.70 \pm 5.173$ \\
+/Nep1A & $64.10 \pm 4.927$ & $62.10 \pm 5.288$ & $59.50 \pm 5.300$ \\
MB-Gal80;C316/+ & $63.25 \pm 4.366$ & $52.36 \pm 7.890$ & $65.25 \pm 7.345$ \\
MB-Gal80;c316/Nep2A & $62.83 \pm 3.946$ & $47.17 \pm 5.455$ & $73.13 \pm 4.155$ \\
+/Nep2A & $77.67 \pm 3.530$ & $60.15 \pm 4.650$ & $69.13 \pm 8.532$ \\
MB-Gal80;3316/+ & $58.43 \pm 5.149$ & $49.00 \pm 4.472$ & $54.56 \pm 3.986$ \\
MB-Gal80;c316/Nep3A & $52.50 \pm 4.056$ & $54.75 \pm 6.648$ & $53.42 \pm 4.763$ \\
+/Nep3A & $73.70 \pm 4.261$ & $51.17 \pm 6.457$ & $54.33 \pm 3.945$ \\
MB-Gal80;(316/+ & $58.57 \pm 4.961$ & $52.33 \pm 4.330$ & $58.56 \pm 4.628$ \\
MB-Gal80;3316/Nep4A & $56.90 \pm 8.849$ & $52.00 \pm 4.424$ & $62.00 \pm 4.149$ \\
+/Nep4A & $58.30 \pm 5.863$ & $53.08 \pm 5.016$ & $52.08 \pm 3.718$ \\
\hline
\end{tabular}

Data are shown as means \pm SEM. All genotypes tested exhibit normal shock reactivity (Nep1A: $F_{(2,29)}=0.6487$ $p=0.5307, n=10 ;$ Nep2A: $F_{(2,35)}=4.544, p=0.0181, n=12$, post-hoc Newman-Keuls test, MB-Gal80;c316/ Nep2A vs $+/$ Nep2A $* p<0.05 ;$ Nep3A: $F_{(2,26)}=6.699, p=0.0049, n \geq 7$, post hoc Newman-Keuls test, $M B$ Gal80:c316/Nep3A vs $+/$ Nep3A ${ }^{* *} p<0.01 ;$ Nep4A: $\left.F_{(2,26)}=0.01578, p=0.9844, n \geq 7\right)$ and normal olfactory acuity for octanol (Nep1A: $F_{(2,27)}=0.2913, p=0.7498, n \geq 8$; Nep2A: $F_{(2,35)}=1.249, p=0.3000, n \geq 11$; Nep3A: $F_{(2,32)}=0.2108, p=0.8111, n \geq 9$; Nep4A: $\left.F_{(2,32)}=0.01515, p=0.9850, n \geq 9\right)$ and methylcyclohexanol (Nep1A: $F_{(2,29)}=0.03746, p=0.9633, n=10 ; \operatorname{Nep2A:} F_{(2,23)}=0.3230, p=0.7275, n=8$; Nep3A: $F_{(2,32)}=0.01955, p=0.9807, n \geq 9 ;$ Nep4A: $\left.F_{(2,32)}=1.609, p=0.2168, n \geq 9\right)$.

VT64246). The expression of each RNAi-Nep tested led to significant MTM deficits (Fig. 4A). These deficits were not observed when flies were incubated under nonpermissive temperature (Fig. 4B), which shows that the deficits were caused specifically by RNAi induction in adult DPM neurons. We further verified that $G a l 80^{\text {ts }}$;VT64246/Nep1A, /Nep2A, /Nep3A, and $/ N e p 4 A$ flies were able to perceive the conditioning stimuli normally. All of the genotypes tested showed normal shock reactivity and normal olfactory acuity to each odor after electric shock exposure (Table 4).

The RNAi constructs used in this study did not show any predicted off-target regions (Vienna Drosophila Resource Center and dscheck.rnai.jp). However, to strengthen our data, we used another nonoverlapping RNAi sequence for each neprilysin. As we did for Nep1B, we constructed lines encoding RNAi-Nep2B, $3 \mathrm{~B}$, or $4 \mathrm{~B}$ construct and Dicer2 (Nep2B, Nep3B, and Nep4B). When expressed for $3 \mathrm{~d}$ under the control of the $\mathrm{Gal} 0^{\mathrm{ts}}$; VT64246 driver, these constructs led to significant MTM deficits (Fig. 4C) that were not apparent when flies were incubated at nonpermissive temperature (Fig. 4D), thus showing that they were caused specifically by RNAi induction in adult DPM neurons. We verified that Gal80 ${ }^{\text {ts }}$;VT64246/Nep1B, /Nep2B, /Nep3B, /Nep4B flies displayed normal shock sensitivity and olfactory acuity (Table 4 ). Together, the data establish that all four neprilysins are required in adult DPM neurons for MTM.

\section{Nep1, Nep3, and Nep4 are required in adult DPM neurons for LTM}

To further characterize neprilysin function in DPM neurons we then studied the other memory phases. We first analyzed the effect of neprilysin silencing in adult DPM neurons on learning. After $3 \mathrm{~d}$ of induction, all genotypes tested displayed normal learning (Fig. 5A), showing that inhibiting the expression of any neprilysin in adult DPM neurons does not disrupt this process. Because we observed functional redundancy in the MB among Nep2, Nep3, and Nep4, we also analyzed triple silencing in adult DPM neurons. Gal80 ${ }^{\text {ts }}$;VT64246/Nep2A;Nep3A;Nep4A flies exhibited wild-type learning scores (Fig. 5B). We then assessed ARM formation. After induction, Gal80 ${ }^{\text {ts }}$;VT64246/Nep flies ex- 
A

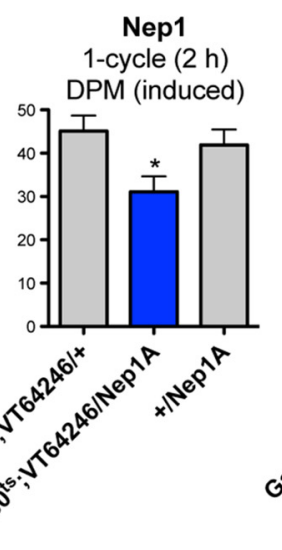

B
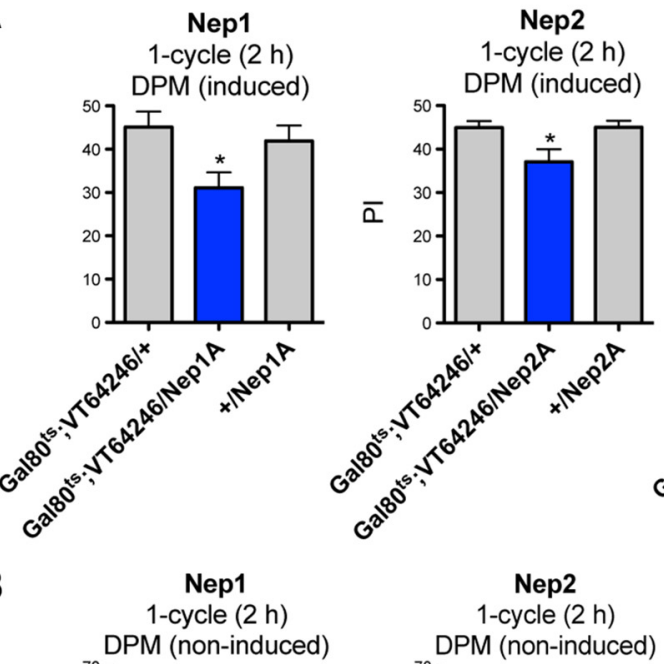

Nep2
1-cycle (2 h)

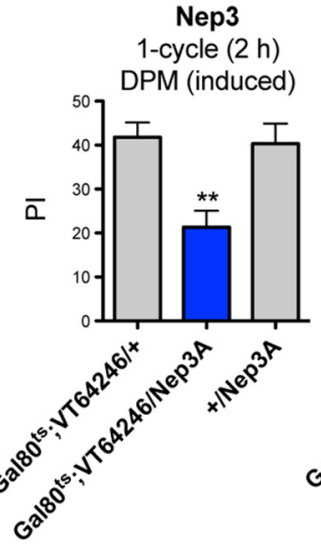

Nep3

1-cycle (2h)

DPM (induced)
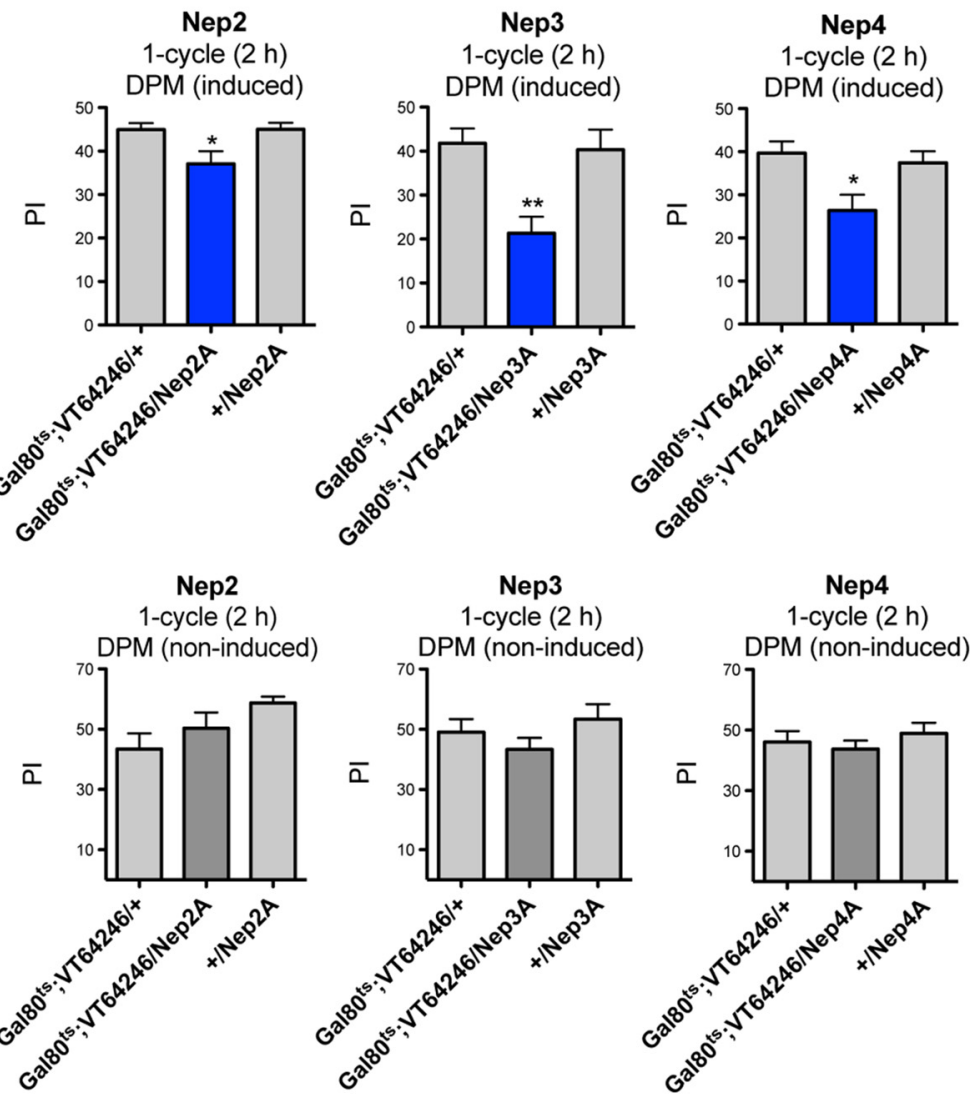

C
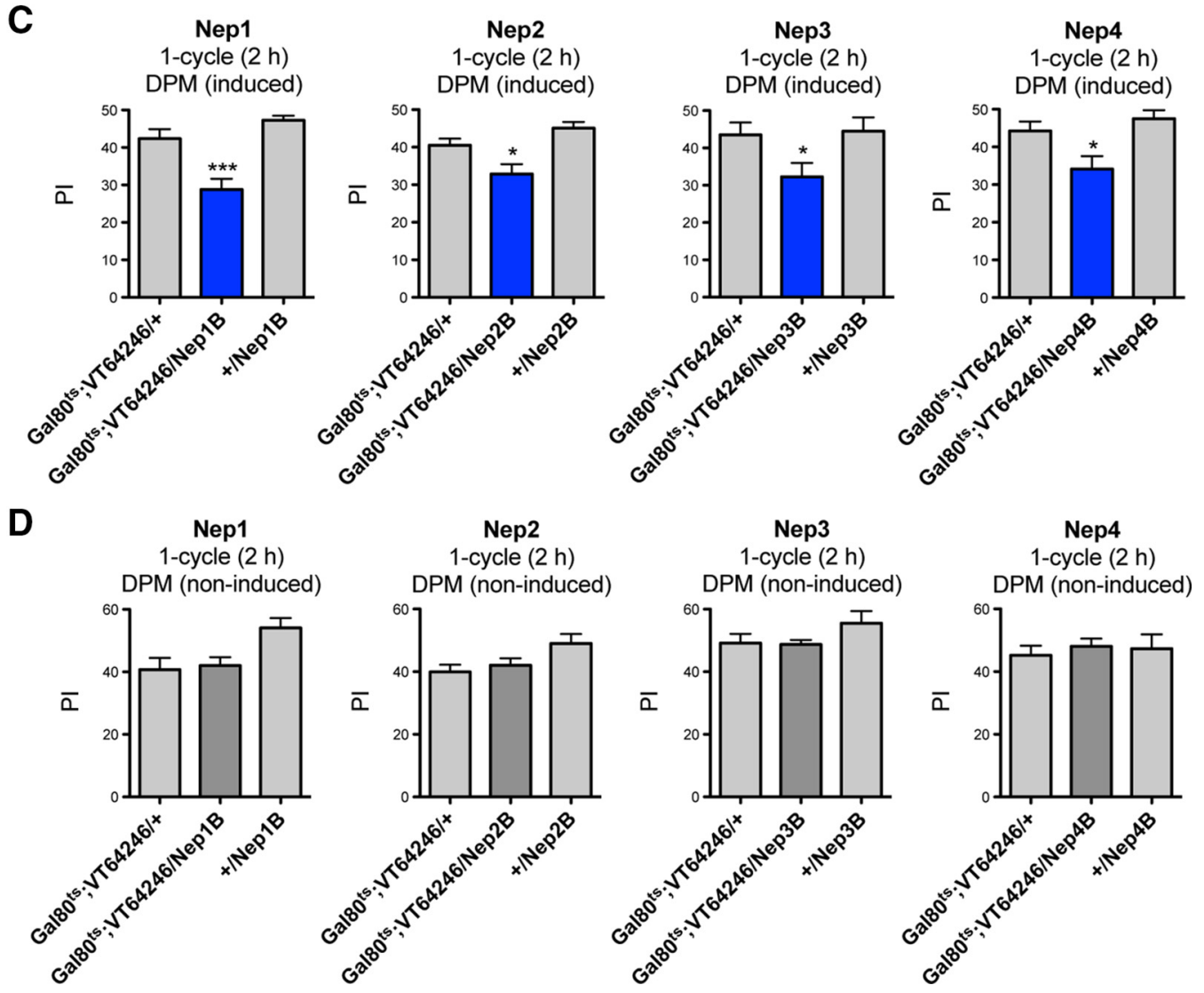

Figure 4. Neprilysin inhibition in adult DPM neurons induces MTM deficits. $A, B$, MTM analyses of flies expressing RNAi-Nep(A) in adult DPM neurons. $A$, After $3 \mathrm{~d}$ of induction, Gal80 $0^{\text {ts; }}, V T 64246$ / Nep1A, /Nep2A, /Nep3A and /Nep4A flies exhibit MTM deficits compared with the genetic controls (Nep1A: $F_{(2,73)}=4.125, p=0.0202, n \geq 23$, post hoc Newman-Keuls test, Gal80 $0^{\text {ts; }}$ VT64246/ Nep1A vs Gal80 ${ }^{\text {ts }} ;$ VT64246/+ ${ }^{*} p<0.05$, Gal80 $;$; VT64246/Nep1A vs $+/$ Nep $1 A *^{*} p<0.05 ;$ Nep2A: $F_{(2,34)}=4.729, p=0.0159, n \geq 11$, post hoc Newman-Keuls test, Gal80 ${ }^{\text {ts }} ;$ VT64246/Nep2A vs Gal80 ${ }^{\text {ts }} ;$ VT64246/ $+{ }^{*} p<0.05$, Gal80 ${ }^{\text {ts }} ;$ VT64246/Nep2A vs $+/$ Nep2A ${ }^{*} p<0.05 ;$ Nep3A: $F_{(2,28)}=8.327, p=0.0016, n \geq 9$, post hoc Newman-Keuls (Figure legend continues.) 
Table 4. Shock reactivity and olfactory acuity of flies expressing RNAi-Nep under the control of the Gal80 ${ }^{t s}$;VT64246 driver

\begin{tabular}{|c|c|c|c|}
\hline \multirow[b]{2}{*}{ Genotype } & \multirow[b]{2}{*}{ Shock reactivity } & \multicolumn{2}{|l|}{ Olfactory acuity } \\
\hline & & Octanol & Methylcyclohexano \\
\hline Gal80 $0^{t 5} ; V T 64246 /+$ & $63.43 \pm 6.651$ & $55.27 \pm 5.051$ & $44.50 \pm 6.379$ \\
\hline Gal80 $;$ ivT64246/Nep1A & $71.13 \pm 4.315$ & $49.91 \pm 6.962$ & $45.88 \pm 6.396$ \\
\hline$+/$ Nep1A & $71.38 \pm 8.527$ & $50.10 \pm 6.622$ & $42.75 \pm 13.55$ \\
\hline Gal80 $0^{\text {ts }} ; V T 64246 /+$ & $69.83 \pm 6.705$ & $55.88 \pm 9.542$ & $49.30 \pm 9.745$ \\
\hline Gal80 $; 0^{t s}$ VT64246/Nep2A & $72.63 \pm 5.628$ & $50.10 \pm 8.214$ & $56.50 \pm 6.668$ \\
\hline$+/$ Nep2A & $62.75 \pm 7.250$ & $61.50 \pm 6.841$ & $53.63 \pm 4.594$ \\
\hline Gal80 $0^{\text {ts }} ; V T 64246 /+$ & $57.50 \pm 6.059$ & $55.25 \pm 7.695$ & $61.58 \pm 6.389$ \\
\hline Gal80 $;$ VT64246/Nep3A & $62.88 \pm 3.512$ & $53.30 \pm 9.300$ & $56.11 \pm 7.162$ \\
\hline$+/$ Nep3A & $66.25 \pm 6.922$ & $70.90 \pm 5.921$ & $58.89 \pm 10.88$ \\
\hline Gal80 $0^{\text {ts }} ;$ VT64246/+ & $68.17 \pm 8.392$ & $66.80 \pm 4.098$ & $57.27 \pm 3.996$ \\
\hline Gal80's $;$ VT64246/Nep4A & $79.88 \pm 4.510$ & $64.60 \pm 4.815$ & $51.00 \pm 3.827$ \\
\hline$+/$ Nep4A & $77.75 \pm 5.778$ & $55.60 \pm 7.365$ & $48.78 \pm 3.403$ \\
\hline Gal80's.VVT64246/+ & $60.30 \pm 4.652$ & $57.00 \pm 4.110$ & $46.40 \pm 5.594$ \\
\hline Gal80's $;$ VT64246/Nep1B & $67.30 \pm 3.718$ & $49.30 \pm 4.258$ & $53.20 \pm 5.884$ \\
\hline$+/$ Nep1B & $66.90 \pm 5.992$ & $53.30 \pm 4.507$ & $48.10 \pm 5.176$ \\
\hline Gal80 $0^{\text {ts }} ;$ VT64246/+ & $65.38 \pm 3.891$ & $50.56 \pm 4.998$ & $43.00 \pm 3.990$ \\
\hline Gal80 $0^{\text {ts }} ;$ VT64246/Nep2B & $63.60 \pm 4.710$ & $50.71 \pm 3.640$ & $45.00 \pm 2.736$ \\
\hline$+/$ Nep2B & $75.90 \pm 4.067$ & $47.36 \pm 3.832$ & $46.93 \pm 3.311$ \\
\hline Gal80's.VVT64246/+ & $82.08 \pm 3.773$ & $54.63 \pm 7.620$ & $46.33 \pm 6.954$ \\
\hline Gal80 $;$ it VT64246/Nep3B & $76.60 \pm 2.831$ & $62.67 \pm 7.754$ & $53.83 \pm 7.483$ \\
\hline$+/$ Nep3B & $77.93 \pm 2.861$ & $54.17 \pm 7.213$ & $47.33 \pm 6.740$ \\
\hline Gal80 $;$ iVT64246/+ & $79.88 \pm 3.618$ & $61.56 \pm 5.984$ & $40.11 \pm 3.318$ \\
\hline Gal80 $0^{t s} ;$ VT64246/Nep4B & $70.70 \pm 4.407$ & $51.93 \pm 4.673$ & $42.86 \pm 2.526$ \\
\hline$+/ \operatorname{Nep} 4 B$ & $75.50 \pm 4.086$ & $52.36 \pm 4.691$ & $47.64 \pm 4.437$ \\
\hline
\end{tabular}

Data are shown as means \pm SEM. After 3 d of induction, flies show normal shock reactivity (Nep1A: $F_{(2,22)}=0.4276$ $p=0.6579, n \geq 7 ;$ Nep2A: $F_{(2,21)}=0.6423, p=0.5371, n \geq 6$; Nep3A: $F_{(221)}=0.5587, p=0.5811, n \geq 6$; Nep4A: $F_{(2,21)}=0.9509, p=0.4040, n \geq 6, \operatorname{Nep} 1 \mathrm{~B}: F_{(2,29)}=0.6496, p=0.5302, n=10 ; \mathrm{Nep} 2 \mathrm{~B}: F_{(2,27)}=2.498$, $\left.p=0.1026, n \geq 8 ; \operatorname{Nep} 3 \mathrm{~B}: F_{(2,41)}=0.7835, p=0.4639, n \geq 12 ; \operatorname{Nep} 4 \mathrm{~B}: F_{(2,27)}=1.185, p=0.3225, n \geq 8\right)$ and normal olfactory acuity for octanol (Nep1A: $F_{(2,31)}=0.2410, p=0.7874, n \geq 10$; Nep2A: $F_{(2,27)}=0.5280, p=$ $0.5962, n \geq 8 ;$ Nep3A: $F_{(2,27)}=1.593, p=0.2232, n \geq 8$; Nep4A: $F_{(2,29)}=1.121, p=0.3406, n=10$, Nep1B: $F_{(2,29)}=0.8040, p=0.4580, n=10 ; \operatorname{Nep} 2 \mathrm{~B}: F_{(2,36)}=0.2337, p=0.7928, n \geq 9 ;$ Nep3B: $F_{(2,31)}=0.4174, p=$ $\left.0.6627, n \geq 8 ; \operatorname{Nep4B:} F_{(2,36)}=0.9737, p=0.3880, n \geq 9\right)$ and methylcyclohexanol (Nep1A: $F_{(2,27)}=0.02737$ $p=0.9730, n \geq 8 ;$ Nep2A: $F_{(2,25)}=0.2235, p=0.8015, n \geq 8 ;$ Nep3A: $F_{(2,29)}=0.1186, p=0.8886, n \geq 9$; Nep4A: $F_{(2,29)}=1.372, p=0.2706, n \geq 9$, Nep1B: $F_{(2,29)}=0.4053, p=0.6708, n=10 ;$ Nep2B: $F_{(2,36)}=0.3242$, $\left.p=0.7253, n \geq 9 ; \operatorname{Nep3B}: F_{(2,35)}=0.3322, p=0.7197, n=12 ; \operatorname{Nep} 4 B: F_{(2,36)}=1.044, p=0.3630, n \geq 9\right)$.

\footnotetext{
$\leftarrow$

(Figure legend continued.) test, Gal80 ${ }^{\text {ts }}$;TT64246/Nep3A vs Gal80 ${ }^{\text {ts }}, \mathrm{VT} 64246 /+{ }^{* *} p<0.01$, Gal80 ${ }^{\text {ts }} ;$ VT64246/Nep3A vs $+/$ Nep3A ${ }^{* *} p<0.01 ;$ Nep4A: $F_{(2,73)}=5.493, p=0.0061, n \geq$ 24, post hoc Newman-Keuls test, Gal80 $0^{\text {ts }} ;$ VT64246/Nep4A vs Gal80 ${ }^{\text {ts }} ; V T 64246 /+{ }^{* *} p<0.01$, Gal80 ${ }^{\text {ts }} ;$ VT64246/Nep4A vs $+/$ Nep $\left.4 A^{*} p<0.05\right)$. B , Noninduced flies show similar MTM scores to the genetic controls (Nep1A: $F_{(2,26)}=1.300, p=0.2910, n \geq 8$; Nep2A: $F_{(2,26)}=2.942$, $p=0.0720, n \geq 7 ; \operatorname{Nep} 3 \mathrm{~A}: F_{(2,35)}=1.323, p=0.2801, n=12 ; \operatorname{Nep} 4 \mathrm{~A}: F_{(2,58)}=0.5983, p=$ $0.5532, n \geq 19)$. C, D, MTM analyses of flies expressing RNAi-Nep(B) in adult DPM neurons. $C$, After $3 \mathrm{~d}$ of induction, Gal80 ${ }^{\text {ts }}$;VT64246/Nep 1B,/Nep2B,/Nep3B and/Nep4B flies exhibit significantly lower MTM scores than the genetic controls (Nep1B: $F_{(2,41)}=17.03, p<0.0001$, $n=14$, post hoc Newman-Keuls test, Gal80 $;$ VT64246/Nep1B vs Gal80 ${ }^{\text {t5 }} ;$ VT64246/ $+{ }^{* * *} p<$ 0.001, Gal80 ${ }^{\text {t5 }}$,VT64246/Nep1B vs +/Nep1B ${ }^{* * *} p<0.001$; Nep2B: $F_{(2,39)}=9.124, p=$ $0.0006, n \geq 12$, post hoc Newman-Keuls test, Gal80 ${ }^{\text {ts }} ;$ VT64246/Nep2B vs Gal $80^{\text {ts }} ;$ VT $64246 /+$ ${ }^{*} p<0.05$, Gal80 ${ }^{\text {ts }} ;$ VT64246/Nep2B vs + $/$ Nep2B ${ }^{* * *} p<0.001 ;$ Nep3B: $F_{(2,44)}=3.669$, $p=0.0340, n \geq 13$, post hoc Newman-Keuls test, Gal80 ${ }^{\text {ts }} ;$ VT64246/Nep3B vs Gal80 ${ }^{\text {ts }}$; VT64246/ $+{ }^{*} p<0.05$, Gal80 ${ }^{\text {ts }}$,VT64246/Nep3B vs $+/$ Nep $3 B{ }^{*} p<0.05 ;$ Nep4B: $F_{(2,53)}=$ $6.527, p=0.0030, n \geq 15$, post hoc Newman-Keuls test, Gal80 ${ }^{\text {ts }} ;$ VT64246/Nep4B vs Gal80 ${ }^{\text {ts }}$; VT64246/+ ${ }^{*} p<0.05$, Gal80 $;$ VT64246/Nep4B vs $+/$ Nep4B $\left.{ }^{* *} p<0.01\right)$. D, Noninduced flies show normal MTM scores (Nep1B: $F_{(2,30)}=5.178, p=0.0122, n \geq 10$, posthoc NewmanKeuls test, Gal80 ${ }^{\text {ts}}$;VT64246/Nep1B vs +/Nep1B ${ }^{*} p<0.05 ;$ Nep2B: $F_{(2,33)}=3.422, p=$ $0.0454, n \geq 10 ;$ Nep3B: $F_{(2,32)}=1.703, p=0.1993, n=11 ; \operatorname{Nep4B:} F_{(2,33)}=0.1703, p=$ $0.8442, n \geq 10$ ).
}

hibited wild-type ARM scores (Fig. 5C). Similar results were observed with Nep2 + Nep3 + Nep4 silencing in adult DPM neurons (Fig. 5D). Together, the data suggest that neprilysin expression in adult DPM neurons is not required for normal aversive learning and ARM.

We next analyzed the effect of neprilysin silencing in adult DPM neurons on LTM. After induction at $30^{\circ} \mathrm{C}, \mathrm{Gal}^{\mathrm{ts}}{ }^{\text {ts }}$; VT64246/Nep1A, /Nep3A, and /Nep4A flies showed significantly lower LTM scores than their genetic controls (Fig. $5 E$ ). These LTM deficits were specific to RNAi-Nep induction in adult DPM neurons because Gal80 ${ }^{\text {ts }}$;VT64246/RNAi-Nep flies incubated at $18^{\circ} \mathrm{C}$ showed wild-type LTM (Fig. $5 F$ ). Therefore, Nep1, Nep3, and Nep4 are each involved in LTM formation in DPM neurons. In contrast, Nep2 inhibition in adult DPM neurons $\left(\right.$ Gals0 ${ }^{\text {ts }}$; VT64246/Nep2A) did not alter memory scores measured $24 \mathrm{~h}$ after spaced conditioning (Fig. $5 G$ ). To validate that the memory formed in this case was indeed LTM, we ran CXM treatments. It has been shown that LTM formation is specifically sensitive to CXM because it is the only memory phase dependent on de novo protein synthesis (Tully et al., 1994). As expected, when wild-type (+) and Gal $0^{\text {ts }} ; V T 64246 /+$ control flies were fed with CXM, LTM scores decreased significantly (Fig. $5 H$ ). Gal80 $0^{\text {ts }} ; V T 64246 /$ Nep2A flies fed with CXM exhibited significantly lower memory scores compared with same-genotype flies not fed CXM and similar scores to control flies (Fig. $5 H$ ). The data thus demonstrate that inhibition of Nep2 expression in adult DPM neurons does not alter LTM. Together, the results show that Nep1, Nep3, and Nep4 expression are required in adult DPM neurons for LTM formation.

\section{Discussion}

Research on neprilysins has essentially focused on their role as the main $\mathrm{A} \beta$-degrading enzymes in pathological situations and as biomarkers in heart failure. Here, using Drosophila, we established that neprilysins are involved in specific types of memory. Disrupting the expression of any neprilysin impairs MTM and LTM, revealing that one or several neuropeptides need to be targeted to enable proper memory formation. Interestingly, all four neprilysins expressed in the fly are required in the $\mathrm{MB}$ and also in DPM neurons, a pair of large neurons that broadly innervates the $\mathrm{MB}$ and are involved in memory consolidation.

Neprilysins have been described extensively as proteases acting on substrates of no more than 50 residues (Oefner et al., 2000), except Drosophila Nep4, which is involved in muscle integrity independently of its catalytic activity (Panz et al., 2012). There is a consensus that neprilysins function by turning off neuropeptide signals at the synapse (Turner, 2003). In addition, there is evidence to suggest that neprilysin processing could lead to the activation of neuromodulators (Gourlet et al., 1997; Rose et al., 2009). Therefore, in addition to their role in $A \beta$ degradation, neprilysins also inactivate a large number of peptides and are thus equally involved in a large number of processes.

In Drosophila, several small peptides have been linked to olfactory memory. Short neuropeptide F (sNPF) is highly expressed in the MB and has been described as a functional neuromodulator of appetitive memory (Knapek et al., 2013). Drosophila neuropeptide F (dNPF) has been shown to provide a motivational switch in the MB that controls appetitive memory output (Krashes et al., 2009). Interestingly, dNPF is an ortholog of mammalian NPY (Brown et al., 1999), a peptide identified as an hNEP substrate (Rose et al., 2009). hNEP can process NPY in transgenic mice to produce neuroactive fragments. Because components of dNPF/NPY signaling are conserved at both the functional and molecular levels, it is possible that dNPF is 
A

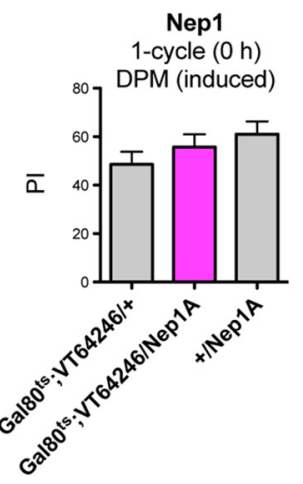

C

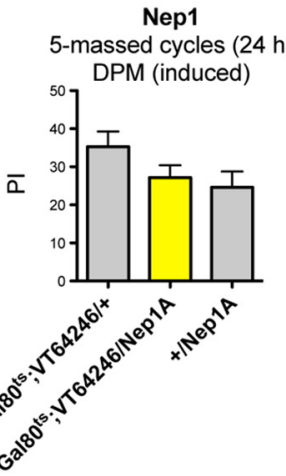

E

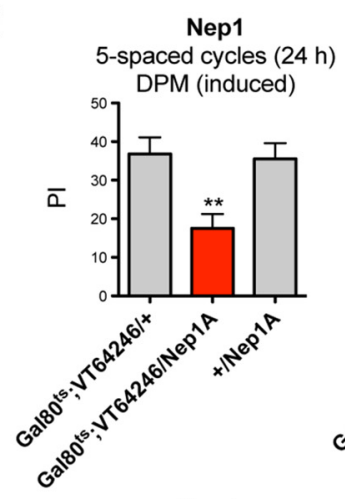
Nep1
5-spaced cycles (24 h)
DPM (non-induced)

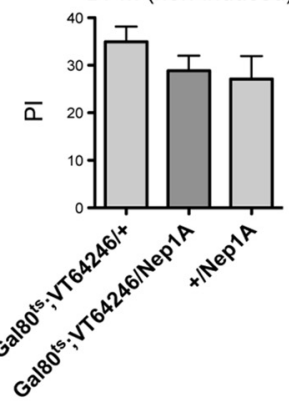

Nep2

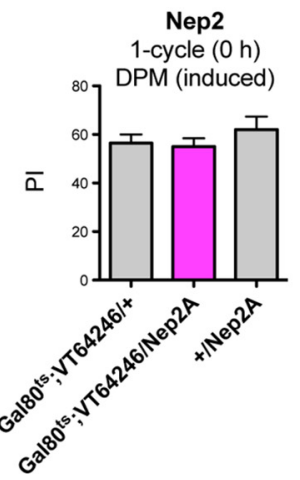

Nep2 5-massed cycles (24 h) DPM (induced)

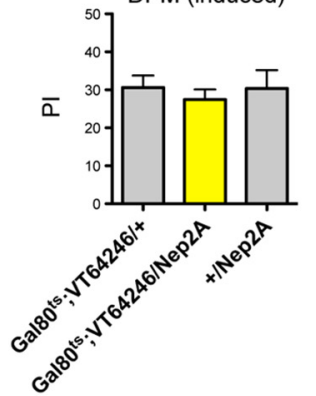

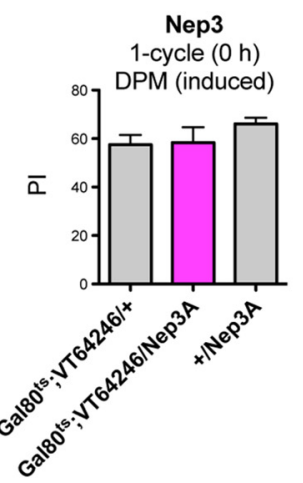

Nep3

5-massed cycles (24 h) DPM (induced)
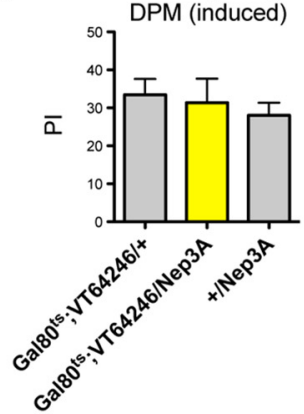

Nep4

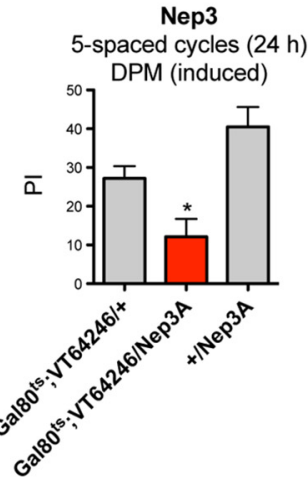

Nep3

5-spaced cycles (24 h) DPM (non-induced)

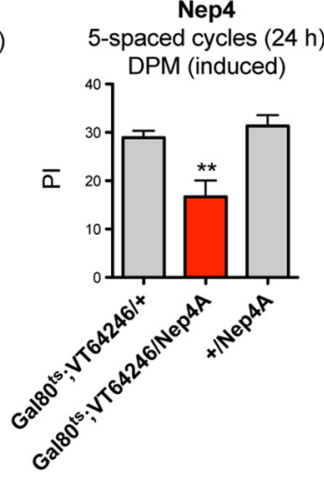

Nep4

5-spaced cycles (24 h) DPM (non-induced)

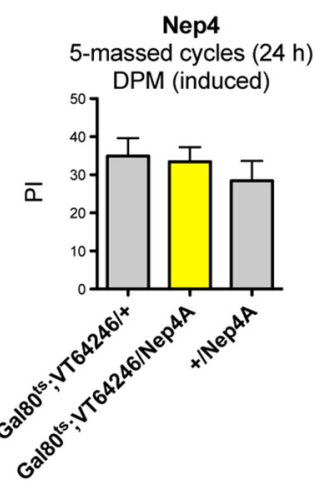

B $\quad \mathrm{Nep} 2+\mathrm{Nep} 3+\mathrm{Nep} 4$
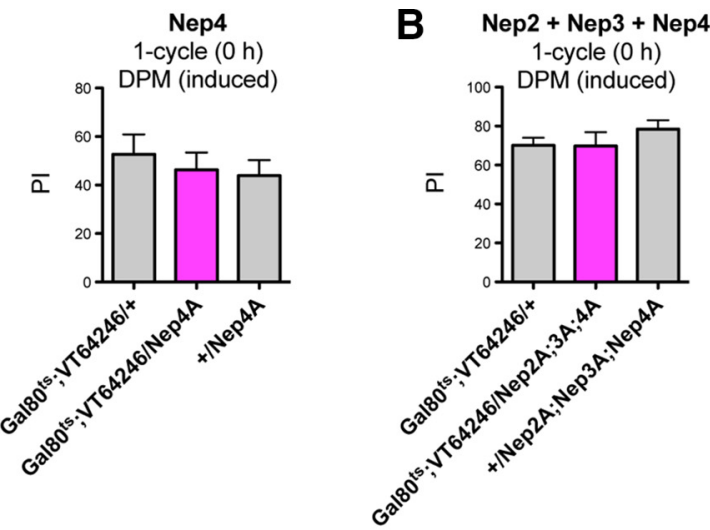

D $\mathrm{Nep} 2+\mathrm{Nep} 3+\mathrm{Nep} 4$ 5 -massed cycles $(24 \mathrm{~h})$ DPM (induced)

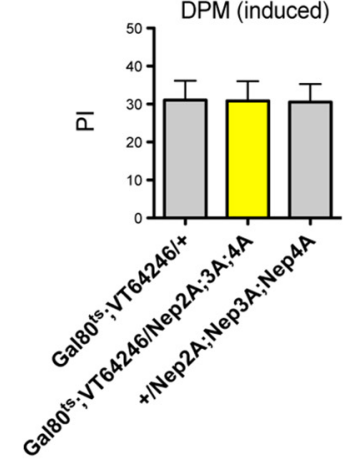

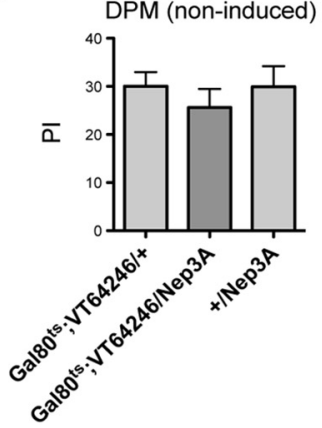
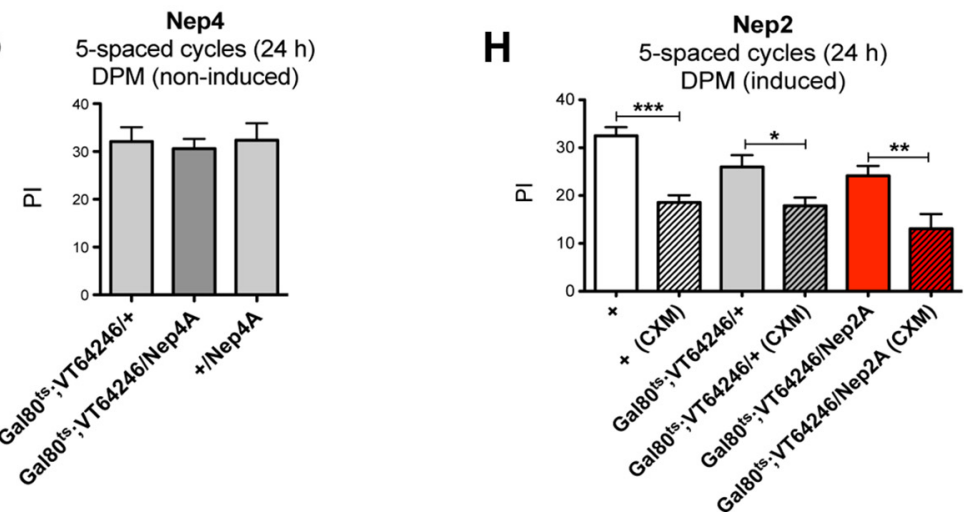

Figure 5. Nep1, Nep3 and Nep4 are required in adult DPM neurons for LTM. $\boldsymbol{A}, \boldsymbol{B}$, Neprilysin silencing in adult DPM neurons does not alter learning. $\boldsymbol{A}$, Gal80 $0^{\text {ts }} ; V T 64246 / N e p 1 A, / N e p 2 A, / N e p 3 A$ and /Nep4A flies display similar learning scores to controls (Nep1A: $F_{(2,24)}=1.296, p=0.2936, n \geq 7 ; \operatorname{Nep} 2 \mathrm{~A}: F_{(2,29)}=0.7634, p=0.4759, n=10 ;$ Nep3A: $F_{(2,21)}=1.057, p=0.3671, n \geq 6$; Nep4A: $\left.F_{(2,26)}=0.3883, p=0.6824, n=9\right)$. $\boldsymbol{B}$, Concomitant silencing of Nep2, Nep3, and Nep4 does not affect learning. Gal80 ${ }^{\text {ts }}$; VT64246/Nep2A;Nep3A;Nep4A flies exhibit similar learning scores to the genetic controls $\left(F_{(2,25)}=0.8933, p=0.423, n \geq 8\right)$. C, D, Neprilysin silencing in adult DPM neurons does not alter ARM. C, Gal80 $;$; VT64246/Nep1A, /Nep2A,/Nep3A, and /Nep4A flies display similar memory scores to controls (Nep1A: $F_{(2,36)}=2.079, p=0.1407, n \geq 12$; Nep2A: $F_{(2,37)}=0.2217, p=0.8022, n \geq 10 ;$ Nep3A: $F_{(2,31)}=0.3567, p=0.7030, n \geq 10$; Nep4A: $\left.F_{(2,34)}=0.5298, p=0.5938, n \geq 11\right)$. D, Gal80 ${ }^{\text {ts }} ;$ VT64246/Nep2A;Nep3A;Nep4A flies exhibit normal ARM scores $\left(F_{(2,39)}=0.0344, p=0.9966, n \geq 13\right)$. $\boldsymbol{E}-\boldsymbol{H}$, Nep1, Nep3, and Nep4 are required in DPM neurons for LTM. E, Gal80 $0^{\text {t5 }}$ VTT64246/Nep1A, /Nep3A and /Nep4A flies show LTM deficits (Nep1A: $F_{(2,37)}=7.369, p=0.0021, n \geq 10$, post hoc Newman-Keuls test, Gal80 ${ }^{\text {ts }}$; VT64246/Nep1A vs Gal80 ${ }^{\text {ts }}$,VT64246/+ ${ }^{* *} p<0.01$, Gal80 ${ }^{\text {t5 }}$,VT64246/Nep1A vs $+/$ Nep1A ${ }^{* *} p<0.01$; Nep3A: $F_{(2,45)}=10.49, p=0.0002, n \geq 15$, post hoc (Figure legend continues.) 
targeted by neprilysins. It remains to be determined whether such peptides are involved in aversive memory and, conversely, whether neprilysins are involved in appetitive memory.

Although all four Drosophila neprilysins are involved in identical memory phases, they exhibit distinct features in terms of the neuronal circuits involved. Only Nep1 inhibition in $\alpha / \beta \mathrm{MB}$ and DPM neurons alters both MTM and LTM. One hypothesis is that Nep1 expressed in DPM and MB neurons plays the same role, targeting a single substrate at synapses connecting the two structures. If so, the lifetime of such a substrate would need to be restricted strictly to limit its effect.

Like the other neprilysins, Nep2 is involved in MTM and LTM, but it exhibits a peculiar characteristic: Nep2 inhibition in DPM neurons leads to MTM disruption, whereas it does not alter LTM. Although we cannot rule out that Nep2 expression in DPM neurons is required for LTM, but that its silencing does not reach a level critical for this process, the data suggest that Nep2 expression in DPM neurons is not required for LTM formation. It is noteworthy that neprilysins are synthesized as type II integral membrane proteins (Turner et al., 2001), whereas Nep2 is a soluble secreted endopeptidase (Thomas et al., 2005; Bland et al., 2007). Whether an endopeptidase is tethered or fully secreted will have important implications in terms of field of activity and enzyme concentration at the membrane surface. It is possible that Nep2 secreted from either DPM neurons or another structure in the vicinity, such as $\mathrm{MB}$ neurons, is able to play an identical role. Therefore, Nep2 reduction in either neuronal structure would not be sufficient to affect LTM. In contrast, Nep2 expression in such a structure would not be able to compensate Nep2 silencing in DPM neurons for MTM, pointing to a distinct requirement for MTM and LTM formation. Nep2 might be required at a distinct concentration and/or localization for MTM and LTM or it may target distinct substrates for these two processes.

The data reveal functional redundancy among Nep2, Nep3, and Nep4 for LTM formation in the $\alpha / \beta$ neurons. Namely, concomitant silencing of Nep2 + Nep3 or Nep3 + Nep4 leads to altered LTM. It is possible that several neprilysins target a single neuropeptide. However, because concomitant silencing of Nep2 + Nep4 does not affect LTM, it seems more likely that several targets are involved in LTM.

The memory phenotypes observed after each neprilysin reduction are reminiscent of the pattern in APPL mutants. Indeed, we showed previously that expression of APPL, the APP fly ortholog, is required in the MB for MTM and LTM formation, but not for learning and ARM (Goguel et al., 2011; Bourdet et al.,

$\leftarrow$

(Figure legend continued.) Newman-Keuls test, Gal80 ${ }^{\text {ts }} ; \mathrm{VT} 64246 / \mathrm{Nep} 3 \mathrm{~A}$ vs Gal $80^{\text {ts}}$; VT64246/+ ${ }^{*} p<0.05$, Gal80 ${ }^{\text {ts }} ;$ VT64246/Nep3A vs $+/$ Nep $3 A^{* * *} p<0.001 ;$ Nep4A: $F_{(2,38)}=$ $10.08, p=0.0003, n=13$, post hoc Newman-Keuls test, Gal80 ${ }^{\text {ts }} ;$ VT64246/Nep 4 A vs Gal $80^{\text {ts }}$; VT64246/+ ${ }^{* *} p<0.01$, Gal80 ${ }^{\text {ts }} ;$ VT64246/Nep4A vs $+/$ Nep4A $\left.{ }^{* * *} p<0.001\right)$. $\boldsymbol{F}$, In the absence of induction, Gal80 ${ }^{\text {ts}}$;VT64246/Nep 1A,/Nep3A and / Nep4A flies display similar LTM scores to the genetic controls (Nep1A: $F_{(2,67)}=1.316, p=0.2752, n \geq 20$; Nep3A: $F_{(2,53)}=0.4687$, $p=0.6285, n \geq 17 ;$ Nep4A: $\left.F_{(2,39)}=0.1010, p=0.9042, n \geq 13\right)$. $\boldsymbol{G}, \boldsymbol{H}$, Nep2 silencing in DPM neurons does not impact LTM. G, Gal80 ${ }^{\text {ts }} ;$ VTT64246/Nep2A flies exhibit similar LTM scores to controls (Nep2A: $\left.F_{(2,47)}=0.5551, p=0.5779, n \geq 15\right)$. $\boldsymbol{H}$, Memory formed after 5 spaced training cycles by Gal80 ${ }^{\mathrm{ts}} ; \mathrm{VT} 64246 / \mathrm{Nep2A}$-induced flies is LTM. Treatment with CXM (CXM) induces a memory decrease for all genotypes tested $\left[F_{(5,88)}=10.87, p<0.0001, n \geq 14\right.$; post hoc Newman-Keuls test, + vs $+(\mathrm{CXM}){ }^{* *} p<0.001$, Gal80 ${ }^{\text {ts }} ; \mathrm{VT} 64246 /+$ vs Gal $80^{\text {ts }}$; VT64246/+ (CXM) ${ }^{*} p<0.05$, Gal80 ${ }^{\text {ts }} ;$ VT64246/Nep2A vs Gal80 ${ }^{\text {ts }} ;$ VT64246/Nep2A (CXM) $\left.{ }^{* *} p<0.01\right]$. After CXM treatment, the remaining memory of $\mathrm{Gal} / 80^{\mathrm{ts}} ; \mathrm{VT} 64246 / \mathrm{Nep} 2 \mathrm{~A}$ flies is similar to that of their genetic control group (post hoc Newman-Keuls test, Gal80 ${ }^{\text {ts }} ;$ VT64246/ Nep2A (CXM) vs Gal80 ${ }^{\text {ts }}$;VT64246/+ (CXM) $\left.p>0.05\right)$.
2015). An attractive hypothesis is that $A \beta$ peptide derived from physiological processing of APPL might play a role in memory and act as a substrate for one of the neprilysin peptidases. Nep2 would be a good candidate because several studies have shown that it is capable of degrading human $\mathrm{A} \beta$ (Finelli et al., 2004; Cao et al., 2008). Supporting this hypothesis, several reports in mammals have implicated low physiological concentrations of $\mathrm{A} \beta$ peptide in memory formation (Puzzo et al., 2008; Garcia-Osta and Alberini, 2009; Morley et al., 2010).

The memory phenotypes observed here are equally reminiscent of the pattern displayed by amnesiac ( $\mathrm{amn}$ ) mutants (Quinn et al., 1979; Feany and Quinn, 1995; DeZazzo et al., 1999; Yu et al., 2006). The amn gene isolated through behavioral screening for memory mutants (Quinn et al., 1979) was later shown to encode a predicted neuropeptide precursor (Feany and Quinn, 1995). Although the mature products of the amn gene have not been identified, sequence analyses suggested the existence of three potential peptides. One of them is homologous to mammalian pituitary adenylate cyclase-activating peptide (PACAP), a neuromodulator and neurotransmitter that regulates a variety of physiological processes through stimulation of cAMP production (Miyata et al., 1989; for review, see Arimura, 1998; Vaudry et al., 2000). In vitro studies have shown that hNEP can degrade PACAP (Gourlet et al., 1997) and the analysis of the biological properties of the resulting fragments found that PACAP degradation by hNEP produces active metabolites selective for a particular receptor subtype. One of the major sites of PACAP cleavage by hNEP is conserved in the AMN peptide. It was shown that $\mathrm{AMN}$ is highly expressed in DPM neurons, where the four neprilysins are required for MTM (Waddell et al., 2000). DPM output is required during the consolidation phase for MTM and it was suggested that DPM might release the AMN modulatory neuropeptide that alters the physiology of MB neurons to help stabilize or consolidate odor memories (Keene et al., 2004). The fact that neuropeptides are often coreleased with classical neurotransmitters, but generally have slower and longer-lasting postsynaptic effects, has prompted the hypothesis that AMN peptides may be released at the $\mathrm{MB}$ to produce relatively long-lasting, physiological changes. Given this context, it is tempting to speculate that AMN might be one of the Drosophila neprilysin's targets.

Both the axons and dendrites of DPM are evenly distributed in different lobes of the MB, and it has been suggested that DPM neurons are presynaptic and postsynaptic to the $\mathrm{MB}$ neurons and are recurrent feedback neurons (Yu et al., 2005; Keene et al., 2006; Wu et al., 2013; review, Perisse et al., 2013). Because neprilysins are necessary in the DPM, and also in the $\alpha / \beta$ neurons of the MB where MTM and LTM are stored (Bouzaiane et al., 2015), these proteins could be involved in maintaining a loop between the DPM and MB lobes by restricting the lifetime of neuromodulators. The DPM- $\alpha / \beta$ neurons circuit has been shown recently to also modulate egg-laying decision via the AMN neuropeptide (Wu et al., 2015). It would be interesting to learn whether neprilysins are involved in this process or if their function is restricted to memory formation.

Despite the importance of the MB for olfactory memory, a functional neurotransmitter or coreleased peptidic neuromodulators produced by MB-intrinsic cells has long remained elusive. It was shown recently that acetylcholine is a Kenyon cell transmitter (Barnstedt et al., 2016). The fact that several neprilysins are required for MTM and LTM suggests the involvement of at least one neuropeptide. It remains to be determined whether neprilysin targets are released from the DPM and/or MB and whether identical or distinct neuropeptide substrates support MTM and 
LTM processes. The sum of the work reported here highlights the critical role of the DPM in inactivating and/or processing neuropeptides involved in memory processes connected to the MB.

\section{References}

Arimura A (1998) Perspectives on pituitary adenylate cyclase activating polypeptide (PACAP) in the neuroendocrine, endocrine, and nervous systems. Jpn J Physiol 48:301-331. CrossRef Medline

Aso Y, Grübel K, Busch S, Friedrich AB, Siwanowicz I, Tanimoto H (2009) The mushroom body of adult Drosophila characterized by GAL4 drivers. J Neurogenet 23:156-172. CrossRef Medline

Barnstedt O, Owald D, Felsenberg J, Brain R, Moszynski JP, Talbot CB, Perrat PN, Waddell S (2016) Memory-relevant mushroom body output synapses are cholinergic. Neuron 89:1237-1247. CrossRef Medline

Bland ND, Thomas JE, Audsley N, Shirras AD, Turner AJ, Isaac RE (2007) Expression of NEP2, a soluble neprilysin-like endopeptidase, during embryogenesis in Drosophila melanogaster. Peptides 28:127-135. CrossRef Medline

Bland ND, Pinney JW, Thomas JE, Turner AJ, Isaac RE (2008) Bioinformatic analysis of the neprilysin (M13) family of peptidases reveals complex evolutionary and functional relationships. BMC Evol Biol 8.

Bourdet I, Préat T, Goguel V (2015) The full-length form of the Drosophila amyloid precursor protein is involved in memory formation. J Neurosci 35:1043-1051. CrossRef Medline

Bouzaiane E, Trannoy S, Scheunemann L, Plaçais PY, Préat T (2015) Two independent mushroom body output circuits retrieve the six discrete components of Drosophila aversive memory. Cell Rep 11:1280-1292. CrossRef Medline

Brand AH, Perrimon N (1993) Targeted gene expression as a means of altering cell fates and generating dominant phenotypes. Development 118: 401-415. Medline

Brown MR, Crim JW, Arata RC, Cai HN, Chun C, Shen P (1999) Identification of a Drosophila brain-gut peptide related to the neuropeptide $\mathrm{Y}$ family. Peptides 20:1035-1042. CrossRef Medline

Caccamo A, Oddo S, Sugarman MC, Akbari Y, LaFerla FM (2005) Age- and region-dependent alterations in $\mathrm{A} \beta$-degrading enzymes: implications for A $\beta$-induced disorders. Neurobiol Aging 26:645-654. CrossRef Medline

Cao W, Song HJ, Gangi T, Kelkar A, Antani I, Garza D, Konsolaki M (2008) Identification of novel genes that modify phenotypes induced by Alzheimer's: amyloid overexpression in Drosophila. Genetics 178:1457-1471. CrossRef Medline

Chintapalli VR, Wang J, Dow JA (2007) Using FlyAtlas to identify better Drosophila melanogaster models of human disease. Nat Genet 39: 715-720. CrossRef Medline

Crittenden JR, Skoulakis EMC, Han KA, Kalderon D, Davis RL (1998) Tripartite mushroom body architecture revealed by antigenic markers. Learn Mem 5:38-51. Medline

de Belle JS, Heisenberg M (1994) Associative odor learning in Drosophila abolished by chemical ablation of mushroom bodies. Science 263: 692-695. CrossRef Medline

DeZazzo J, Xia S, Christensen J, Velinzon K, Tully T (1999) Developmental expression of an amn+ transgene rescues the mutant memory defect of amnesiac adults. J Neurosci 19:8740-8746. Medline

Feany MB, Quinn WG (1995) A neuropeptide gene defined by the Drosophila memory mutant amnesiac. Science 268:869-873. CrossRef Medline

Finelli A, Kelkar A, Song HJ, Yang H, Konsolaki M (2004) A model for studying Alzheimer's A $\beta 42$-induced toxicity in Drosophila melanogaster. Mol Cell Neurosci 26:365-375. CrossRef Medline

Fukami S, Watanabe K, Iwata N, Haraoka J, Lu B, Gerard NP, Gerard C, Fraser P, Westaway D, St George-Hyslop P, Saido TC (2002) A $\beta$ degrading endopeptidase, neprilysin, in mouse brain: synaptic and axonal localization inversely correlating with $\mathrm{A} \beta$ pathology. Neurosci Res 43: 39-56. CrossRef Medline

Garcia-Osta A, Alberini CM (2009) Amyloid beta mediates memory formation. Learn Mem 16:267-272. CrossRef Medline

Gerber B, Scherer S, Neuser K, Michels B, Hendel T, Stocker RF, Heisenberg M (2004) Visual learning in individually assayed Drosophila larvae. J Exp Biol 207:179-188. CrossRef Medline

Goguel V, Belair AL, Ayaz D, Lampin-Saint-Amaux A, Scaplehorn N, Hassan BA, Préat T (2011) Drosophila amyloid precursor protein-like is required for long-term memory. J Neurosci 31:1032-1037. CrossRef Medline

Gourlet P, Vandermeers A, Robberecht P, Deschodt-Lanckman M (1997)
Vasoactive intestinal peptide (VIP) and pituitary adenylate cyclaseactivating peptide (PACAP-27, but not PACAP-38) degradation by the neutral endopeptidase EC 3.4.24111. Biochem Pharmacol 54:509-515. CrossRef Medline

Haynes PR, Christmann BL, Griffith LC (2015) A single pair of neurons links sleep to memory consolidation in Drosophila melanogaster. eLife 4. CrossRef Medline

Heisenberg M (2003) Mushroom body memoir: from maps to models. Nat Rev Neurosci 4:266-275. CrossRef Medline

Hüttenrauch M, Baches S, Gerth J, Bayer TA, Weggen S, Wirths O (2015) Neprilysin deficiency alters the neuropathological and behavioral phenotype in the 5XFAD mouse model of Alzheimer's disease. J Alzheimers Dis 44:1291-1302. CrossRef Medline

Isabel G, Préat T (2008) Molecular and system analysis of olfactory memory in Drosophila. Learn Mem 4:103-118.

Iwata N, Mizukami H, Shirotani K, Takaki Y, Muramatsu S, Lu B, Gerard NP, Gerard C, Ozawa K, Saido TC (2004) Presynaptic localization of neprilysin contributes to efficient clearance of amyloid-beta peptide in mouse brain. J Neurosci 24:991-998. CrossRef Medline

Keene AC, Stratmann M, Keller A, Perrat PN, Vosshall LB, Waddell S (2004) Diverse odor-conditioned memories require uniquely timed dorsal paired medial neuron output. Neuron 44:521-533. CrossRef Medline

Keene AC, Krashes MJ, Leung B, Bernard JA, Waddell S (2006) Drosophila dorsal paired medial neurons provide a general mechanism for memory consolidation. Curr Biol 16:1524-1530. CrossRef Medline

Knapek S, Kahsai L, Winther AM, Tanimoto H, Nässel DR (2013) Short neuropeptide $\mathrm{F}$ acts as a functional neuromodulator for olfactory memory in kenyon cells of Drosophila mushroom bodies. J Neurosci 33: 5340-5345. CrossRef Medline

Krashes MJ, Keene AC, Leung B, Armstrong JD, Waddell S (2007) Sequential use of mushroom body neuron subsets during Drosophila odor memory processing. Neuron 53:103-115. CrossRef Medline

Krashes MJ, DasGupta S, Vreede A, White B, Armstrong JD, Waddell S (2009) A neural circuit mechanism integrating motivational state with memory expression in Drosophila. Cell 139:416-427. CrossRef Medline

Lee PT, Lin HW, Chang YH, Fu TF, Dubnau J, Hirsh J, Lee T, Chiang AS (2011) Serotonin-mushroom body circuit modulating the formation of anesthesia-resistant memoryin Drosophila. Proc Natl Acad Sci U S A 108: 13794-13799. CrossRef Medline

Marr RA, Hafez DM (2014) Amyloid-beta and Alzheimer's disease: the role of neprilysin-2 in amyloid-beta clearance. Front Aging Neurosci 6.

McGuire SE, Le PT, Osborn AJ, Matsumoto K, Davis RL (2003) Spatiotemporal rescue of memory dysfunction in Drosophila. Science 302:17651768. CrossRef Medline

Meyer H, Panz M, Zmojdzian M, Jagla K, Paululat A (2009) Neprilysin 4, a novel endopeptidase from Drosophila melanogaster, displays distinct substrate specificities and exceptional solubility states. J Exp Biol 212: 3673-3683. CrossRef Medline

Meyer H, Panz M, Albrecht S, Drechsler M, Wang S, Hüsken M, Lehmacher C, Paululat A (2011) Drosophila metalloproteases in development and differentiation: the role of ADAM proteins and their relatives. Eur J Cell Biol 90:770-778. CrossRef Medline

Miyata A, Arimura A, Dahl RR, Minamino N, Uehara A, Jiang L, Culler MD, Coy DH (1989) Isolation of a novel 38 residue-hypothalamic polypeptide which stimulates Adenylate Cyclase in pituitary cells. Biochem Biophys Res Commun 164:567-574. CrossRef Medline

Morley JE, Farr SA, Banks WA, Johnson SN, Yamada KA, Xu L (2010) A physiological role for amyloid- $\beta$ protein: enhancement of learning and memory. J Alzheimers Dis 19:441-449. CrossRef Medline

Nalivaeva NN, Belyaev ND, Zhuravin IA, Turner AJ (2012a) The Alzheimer's amyloid-degrading peptidase, neprilysin: can we control it? Int J Alzheimers Dis 2012:383796. CrossRef Medline

Nalivaeva NN, Belyaev ND, Lewis DI, Pickles AR, Makova NZ, Bagrova DI, Dubrovskaya NM, Plesneva SA, Zhuravin IA, Turner AJ (2012b) Effect of sodium valproate administration on brain neprilysin expression and memory in rats. J Mol Neurosci 46:569-577. CrossRef Medline

Oefner C, D'Arcy A, Hennig M, Winkler FK, Dale GE (2000) Structure of human neutral endopeptidase (neprilysin) complexed with phosphoramidon. J Mol Biol 296:341-349. CrossRef Medline

Panz M, Vitos-Faleato J, Jendretzki A, Heinisch JJ, Paululat A, Meyer H (2012) A novel role for the noncatalytic intracellular domain of Neprilysins in muscle physiology. Biol Cell 104:553-568. CrossRef Medline 
Park MH, Lee JK, Choi S, Ahn J, Jin HK, Park JS, Bae JS (2013) Recombinant soluble neprilysin reduces amyloid-beta accumulation and improves memory impairment in Alzheimer's disease mice. Brain Res 1529: 113-124. CrossRef Medline

Pascual A, Préat T (2001) Localization of long-term memory within the Drosophila mushroom body. Science 294:1115-1117. CrossRef Medline

Perisse E, Burke C, Huetteroth W, Waddell S (2013) Shocking revelations and saccharin sweetness in the study of Drosophila olfactory memory. Curr Biol 23:R752-R763. CrossRef Medline

Pham JW, Pellino JL, Lee YS, Carthew RW, Sontheimer EJ (2004) A Dicer2-dependent $80 \mathrm{~S}$ complex cleaves targeted mRNAs during RNAi in Drosophila. Cell 117:83-94. CrossRef Medline

Poirier R, Wolfer DP, Welzl H, Tracy J, Galsworthy MJ, Nitsch RM, Mohajeri MH (2006) Neuronal neprilysin overexpression is associated with attenuation of $A \beta$-related spatial memory deficit. Neurobiol Dis 24:475-483. CrossRef Medline

Puzzo D, Privitera L, Leznik E, Fà M, Staniszewski A, Palmeri A, Arancio O (2008) Picomolar amyloid-beta positively modulates synaptic plasticity and memory in hippocampus. J Neurosci 28:14537-14545. CrossRef Medline

Quinn WG, Sziber PP, Booker R (1979) The Drosophila memory mutant amnesiac. Nature 277:212-214. CrossRef Medline

Rose JB, Crews L, Rockenstein E, Adame A, Mante M, Hersh LB, Gage FH, Spencer B, Potkar R, Marr RA, Masliah E (2009) Neuropeptide Y fragments derived from neprilysin processing are neuroprotective in a transgenic model of Alzheimer's disease. J Neurosci 29:1115-1125. CrossRef Medline

Sitnik JL, Francis C, Hens K, Huybrechts R, Wolfner MF, Callaerts P (2014) Neprilysins: an evolutionarily conserved family of metalloproteases that play important roles in reproduction in Drosophila. Genetics 196: 781-797. CrossRef Medline

Spencer B, Marr RA, Rockenstein E, Crews L, Adame A, Potkar R, Patrick C, Gage FH, Verma IM, Masliah E (2008) Long-term neprilysin gene transfer is associated with reduced levels of intracellular Abeta and behavioral improvement in APP transgenic mice. BMC Neurosci 9:109-112. CrossRef Medline

Thomas JE, Rylett CM, Carhan A, Bland ND, Bingham RJ, Shirras AD, Turner AJ, Isaac RE (2005) Drosophila melanogaster NEP2 is a new soluble member of the neprilysin family of endopeptidases with implications for reproduction and renal function. Biochem J 386:357-366. CrossRef Medline

Tully T, Quinn WG (1985) Classical-conditioning and retention in normal and mutant Drosophila melanogaster. J Comp Physiol A 157:263-277. CrossRef Medline
Tully T, Préat T, Boynton SC, Del Vecchio M (1994) Genetic dissection of consolidated memory in Drosophila. Cell 79:35-47. CrossRef Medline

Turner AJ (2003) Exploring the structure and function of zinc metallopeptidases: old enzymes and new discoveries. Biochem Soc Trans.

Turner AJ, Isaac RE, Coates D (2001) The neprilysin (NEP) family of zinc metalloendopeptidases: genomics and function. Bioessays 23:261-269. CrossRef Medline

Vaudry D, Gonzalez BJ, Basille M, Yon L, Fournier A, Vaudry H (2000) Pituitary adenylate cyclase-activating polypeptide and its receptors: from structure to functions. Pharmacol Rev 52:269-324. Medline

Waddell S, Armstrong JD, Kitamoto T, Kaiser K, Quinn WG (2000) The amnesiac gene product is expressed in two neurons in the Drosophila brain that are critical for memory. Cell 103:805-813. CrossRef Medline

Walther T, Albrecht D, Becker M, Schubert M, Kouznetsova E, Wiesner B, Maul B, Schliebs R, Grecksch G, Furkert J, Sterner-Kock A, Schultheiss HP, Becker A, Siems WE (2009) Improved learning and memory in aged mice deficient in amyloid $\beta$-degrading neutral endopeptidase. PLoS ONE 4:e4590. CrossRef Medline

Wang S, Wang R, Chen L, Bennett DA, Dickson DW, Wang DS (2010) Expression and functional profiling of neprilysin, insulin-degrading enzyme, and endothelin-converting enzyme in prospectively studied elderly and Alzheimer's brain. J Neurochem 115:47-57. CrossRef Medline

Wu CL, Shih MF, Lee PT, Chiang AS (2013) An octopamine-mushroom body circuit modulates the formation of anesthesia-resistant memory in Drosophila. Curr Biol 23:2346-2354. CrossRef Medline

Wu CL, Fu TF, Chou YY, Yeh SR (2015) A single pair of neurons modulates egg-laying decisions in Drosophila. PLoS One 10:e0121335. CrossRef Medline

Yang MY, Armstrong JD, Vilinsky I, Strausfeld NJ, Kaiser K (1995) Subdivision of the Drosophila mushroom bodies by enhancer-trap expression patterns. Neuron 15:45-54. CrossRef Medline

Yasojima K, McGeer EG, McGeer PL (2001) Relationship between beta amyloid peptide generating molecules and neprilysin in Alzheimer disease and normal brain. Brain Res 919:115-121. CrossRef Medline

Yu D, Keene AC, Srivatsan A, Waddell S, Davis RL (2005) Drosophila DPM neurons form a delayed and branch-specific memory trace after olfactory classical conditioning. Cell 123:945-957. CrossRef Medline

Yu D, Akalal DB, Davis RL (2006) Drosophila alpha/beta mushroom body neurons form a branch-specific, long-term cellular memory trace after spaced olfactory conditioning. Neuron 52:845-855. CrossRef Medline

Zhou L, Wei C, Huang W, Bennett DA, Dickson DW, Wang R, Wang D (2013) Distinct subcellular patterns of neprilysin protein and activity in the brains of Alzheimer's disease patients, transgenic mice and cultured human neuronal cells. Am J Transl Res 5:608-621. Medline 